\title{
Os Partidos Dentro e Fora do Poder: A Judicialização como Resultado Contingente da Estratégia Política*
}

\author{
Matthew M. Taylor \\ Luciano Da Ros
}

\section{INTRODUÇÃO}

\begin{abstract}
importância do Supremo Tribunal Federal -STF no sistema políA tico brasileiro contemporâneo parece inconteste, em especial a partir da configuração institucional que emergiu da Constituição brasileira de 1988 e de seus respectivos efeitos sobre o sistema de controle judicial de constitucionalidade das leis. Apesar de não haver concordância entre os vários autores quanto à exata extensão do peso dessa instituição, o papel por ela exercido está longe de ser insignificante. $\mathrm{Na}$ verdade, a presença de robusta bibliografia sobre o tema apenas corrobora esse juízo. Todavia, ainda que os cientistas sociais brasileiros venham se dedicando crescentemente ao tema, a literatura está longe de ter esgotado o assunto. Aspectos concretos dessa realidade e mesmo abordagens teóricas ainda não foram aplicados de modo satisfatório ao caso brasileiro, como alguns autores vêm acertadamente apontando (Koerner e Maciel, 2002:129-131; Carvalho Neto, 2004:123-124). Buscando examinar a questão sob um novo ângulo, propomos esta pesquisa.
\end{abstract}

\footnotetext{
* Agradecemos o trabalho da Editoria da revista DADOS, as sugestões recebidas dos colegas durante o $6^{\circ}$ Encontro da Associação Brasileira de Ciência Política - $\mathrm{ABCP}$, além dos valiosos comentários de dois pareceristas anônimos desta revista.
}

DADOS - Revista de Ciências Sociais, Rio de Janeiro, Vol. 51, nº-4, 2008, pp. 825 a 864. 
Nosso objetivo é analisar os padrões de judicialização da política verificados durante os dois mandatos do presidente Fernando Henrique Cardoso (1995-1998/1999-2002) e compará-los com o período subseqüente de pouco menos de um mandato e meio em que esteve à frente do Poder Executivo o presidente Luiz Inácio Lula da Silva (2003-2006/ 2007-abril de 2008). Inicialmente, o propósito de tal comparação é verificar se ocorreram mudanças ao longo do tempo e dos diferentes governos no acionamento do mais alto tribunal do país para contestação de normas federais por meio do principal instrumento de contestação da vontade majoritária, a Ação Direta de Inconstitucionalidade Adin. Em um segundo momento, passamos à identificação de possíveis causas para as variações - e também para as semelhanças - eventualmente encontradas no levantamento realizado. Em vista disso, este artigo tem início expondo os fundamentos teóricos das indagações que norteiam nossa pesquisa para, em seguida, ser realizada a análise descritiva do fenômeno, somando-se a isso um exame mais detalhado de alguns casos específicos especialmente importantes para o presente estudo.

\section{PARTIDOS E OPOSITORES NA ARENA JUDICIAL}

A proposta de tal tema parte de duas considerações sobre a literatura existente a respeito do assunto, uma de viés analítico e outra de caráter teórico. A primeira observação está voltada diretamente para os trabalhos que os cientistas sociais brasileiros têm produzido sobre o desempenho institucional do mais alto tribunal do país durante o período atual. Poucos, entre esses estudos, abrangem o período de tempo posterior ao governo do presidente Fernando Henrique Cardoso. Os influentes trabalhos de Arantes (1997), Castro (1997a; 1997b) e Werneck Vianna et alii (1999), por exemplo, até mesmo pela época em que foram elaborados, não chegam a ultrapassar esse período. Por outro lado, estudos recentes, como os de Carvalho Neto (2005), Pacheco (2006) e Oliveira (2006), também não examinaram o período posterior ao ano de 2002. Pelo que pudemos constatar, apenas os estudos bastante recentes de Werneck Vianna, Burgos e Salles (2007), Taylor (2008) e Da Ros (2008; no prelo) apresentaram alguma análise do período posterior à eleição do presidente Luiz Inácio Lula da Silva, ainda que integrada a estudos mais amplos sobre o desempenho da instituição. Em vista dessa relativa ausência e da importância dessas abordagens para a compreensão da realidade política brasileira, propomos o estudo do assunto aludido. 
Em segundo lugar, do ponto de vista teórico, devemos observar que o chamamento dos tribunais à apreciação das políticas públicas não resulta apenas da extensão dos canais institucionais existentes para tanto, mas também do contexto e das estratégias políticas de potenciais atores no campo judicial. Como se sabe, a literatura em ciência política adepta do método comparativo está repleta de argumentos sobre as origens institucionais do uso político da via judicial (Clayton e Gillman, 1999; Ríos-Figueroa e Navia, 2005; Ríos-Figueroa e Taylor, 2006; Smith, 1988). O tema central desses estudos se refere ao fato de a estrutura institucional influenciar consideravelmente os padrões de uso das cortes, em especial do ponto de vista comparativo, levando à maior ou à menor contestação judicial da política (ou judicialização da política) em uns casos do que em outros.

Nesse mesmo sentido, devemos observar que há uma literatura crescente relacionada à lógica do uso político-partidário dos tribunais. De acordo com Dotan e Hofnung (2005), uma interessante questão emerge desse particular: por que legisladores fazem uso dos tribunais mesmo quando suas chances de vitória são mínimas e ainda mais se esse mesmo uso pode resultar na restrição da autonomia do próprio Poder Legislativo? A resposta que os autores oferecem é que, a despeito das pequenas chances de sucesso na arena judicial, políticos podem se beneficiar por contestar políticas majoritárias porque angariam em torno de si considerável atenção pública, decorrente em especial da visibilidade que os meios de comunicação dedicam a esses episódios. Em sentido semelhante, Taylor argumentou que os diferentes atores políticos podem fazer uso dos tribunais como veto points que

[...] lhes propiciam retardar ou impedir completamente a implementação de políticas públicas, ou desmerecê-las, ou ainda declarar sua oposição a elas. Esses quatro objetivos táticos (retardar, impedir, desmerecer, declarar) podem ser perseguidos tendo por base sólidos preceitos legais (a forte crença de que uma lei é inconstitucional, por exemplo) e também puros fundamentos estratégicos (por exemplo, um esforço para se recorrer da decisão política apesar do claro reconhecimento de que esse mesmo recurso não tenha qualquer base jurídica) (2008:10; tradução dos autores).

As táticas judiciais, em outras palavras, não estão necessariamente assentadas na expectativa de uma vitória judicial. Por essa mesma razão, encarar a influência política dos tribunais apenas sob a ótica dos casos em que aqueles efetivamente alteram a legislação significa restringir 
sobremaneira a análise e deixar sem apreciação táticas políticas importantes que envolvem os tribunais mesmo em contextos em que a vitória judicial não é esperada.

Ao que parece, os dois aspectos mencionados anteriormente merecem ser congregados. Se, por um lado, é sabido que a configuração institucional importa tanto às cortes quanto a todas as outras instituições, conformando as táticas empregadas pelos políticos e por seus opositores, por outro lado, devemos notar também que tais oponentes não estão apenas interessados nos respectivos resultados judiciais quando recorrem a essa via. De fato, se o custo de desafiar a política nos tribunais é relativamente baixo, há pouca razão para que os oponentes ao governo não façam uso dessa tática. Mesmo que isso não resulte em vitórias judiciais, esses atores podem

[...] levantar dúvidas sobre as políticas adotadas, chamar a atenção pública para supostas ilegalidades procedimentais cometidas ou ainda desmerecer as políticas que buscam suporte majoritário. Ao contestar tais políticas nos tribunais, em outras palavras, pode-se fazer possível assegurar uma vitória sem que se chegue propriamente a uma vitória judicial (ibidem; tradução dos autores).

Ou, como Dotan e Hofnung (2005) sumarizam tão bem em seu título, trata-se de derrotas judiciais e vitórias políticas. Uma vez realizadas tais observações de caráter teórico, nossa expectativa é que possamos contribuir para esse programa de pesquisas. Já se encontra suficientemente estabelecido na literatura que regras institucionais importam, trazendo claros efeitos em termos do uso dos tribunais entre diferentes países e jurisdições. Ademais, sabe-se também que integrantes da oposição possuem tanto razões táticas quanto estratégicas para fazer uso das cortes quando as regras institucionais permitem semelhante utilização.

A questão que permanece, todavia, é a seguinte: sob regras institucionais semelhantes, que fatores contribuem para a variação no uso dos tribunais pelos atores políticos, especialmente por membros da oposição? Recorrendo ao que se pode chamar de "experimento natural" propiciado pelas administrações presidenciais ideologicamente distintas dos presidentes Fernando Henrique Cardoso e Luiz Inácio Lula da Silva, nosso estudo contrasta os padrões de contestação judicial pela oposição nos dois períodos mencionados. Nesse sentido, é de se supor que esse uso político da via judicial resulta da estratégia adotada pelos diferentes 
atores políticos que dela se valem. Essa mesma questão se dirige a um aspecto mais amplo, qual seja: se os diferentes arranjos institucionais permitem maior ou menor participação dos tribunais na arena política, como explicar que diferentes padrões de judicialização da política possam emergir de contextos institucionais praticamente idênticos?

A suposição básica aqui é que, apesar de o desenho institucional influir decisivamente na possibilidade de participação dos tribunais na arena política, estes ainda assim dependem de um acionamento externo para que possam tomar decisões politicamente relevantes. Afinal, de longa data é sabido que o Poder Judiciário, além de não possuir influência sobre o uso da força (a espada) ou sobre o orçamento (a bolsa), também "[...] não pode adotar nenhuma resolução de modo ativo" (Hamilton, 2003:464). Além das mudanças quanto aos integrantes da oposição em cada período, a hipótese levantada nesta pesquisa busca agregar diferenças em relação ao ambiente político e aos assuntos levados à apreciação do mais alto tribunal do país nos dois períodos estudados. Dessa forma, a explicação parece residir nas diferenças quanto aos atores, mas também no que tange à saliência dos temas e ao contexto político em que se processou a dita judicialização, resultado contingente das estratégias políticas adotadas nesses dois períodos. O uso efetivo das táticas judiciais propiciadas pelo arranjo institucional existente não pode ser entendido, portanto, como uma função mecânica do mero oposicionismo ao governo, mas deve integrar também a saliência dos temas tratados e o próprio ambiente político em que semelhante tática é empregada. Interagindo com as respectivas ideologias dos partidos excluídos da coalizão governista, elemento também importante para esta explicação, tais fatores tendem a conformar a utilização efetivamente realizada da contestação judicial das políticas majoritárias pelos diferentes oponentes. Portanto, somente a partir da conjunção de fatores relativos ao teor das políticas prioritárias dos governos (bem como aos interesses que elas atingem) e ao tipo de tática buscada pelos oponentes diante desse contexto, é possível compreender o uso tático das cortes nesse particular (Taylor, 2008:22-23) ${ }^{1}$.

\section{ANÁLISE COMPARATIVA DOS DADOS}

Antes de passarmos à apresentação dos dados descritivos, uma breve revisão do papel da Adin se faz necessária. O uso dessa ação como instrumento político já foi amplamente estudado na literatura recente (Arantes, 1997; Da Ros, 2008; Castro, 1997a; 1997b; Pacheco, 2006; 
Taylor, 2008; Werneck Vianna et alii, 1999; Oliveira, 2005). Reiterando alguns apontamentos desses autores, devemos frisar que as Adins têm sido objeto analítico de interesse dos cientistas políticos especialmente por dois motivos:

1. Por permitir que alguns atores políticos com legitimidade ativa "pulem" a sobrecarga processual dos tribunais inferiores e obtenham uma decisão judicial com efeitos gerais, imediatos e vinculantes. Embora a legitimidade ativa seja restrita a um grupo pequeno de possíveis requerentes, o número de atores legitimados no Brasil é elevado em termos comparativos. Isso tem incentivado o uso intenso do instrumento, redundando em uma média total de duzentas Adins por ano, número que chega a aproximadamente cinqüenta Adins anualmente dirigidas apenas contra atos de órgãos federais (as demais geralmente se voltam contra leis de órgãos estaduais).

2. As decisões nas Adins são irrecorríveis e tomadas com base em revisão abstrata. Isto é, permitindo que o requerente conteste uma determinada lei sem ter de esperar pela manifestação de seus efeitos práti$\cos ^{2}$. Portanto, do ponto de vista político, elas oferecem um instrumento importante de contestação das políticas majoritárias, especialmente para as minorias que não têm voz efetiva nas deliberações dos Poderes Executivo e Legislativo.

Frisamos dois outros pontos relevantes, oriundos da pesquisa realizada:

1. As chances de inviabilizar parcial ou integralmente a legislação por meio das Adins são relativamente elevadas: tomando tanto as decisões de mérito quanto o efeito das liminares, Taylor (2008:87) estima que as chances de uma Adin ser bem-sucedida, isto é, inviabilizar no todo ou em parte determinado estatuto legal, são ligeiramente maiores do que uma em cinco. Nossa análise mostra resultado semelhante: agregando as decisões tomadas contra a legislação tanto no governo Fernando Henrique quanto no governo Lula, chegamos à mesma proporção: 20,1\% das Adins contra leis federais no período de janeiro de 1994 até abril de 2008 resultaram em alguma mudança na legislação contestada. Se considerarmos apenas as Adins que já foram efetivamente julgadas, essa proporção aumenta para 32,6\%, como se pode verificar na Tabela $1^{3}$. Essa intensidade dos julgamentos que inviabilizam parcial ou integralmente estatutos legais federais significa que ocorrem, em média, 9,6 alterações de políticas públicas pela corte por ano, ou seja, quase uma por mês. Considerando que apenas $0,026 \%$ das propostas do 
Executivo votadas pelo Congresso foram rejeitadas na década posterior à Constituição de 1988 (Figueiredo e Limongi, 1999:24), esse papel do STF não pode ser menosprezado.

Tabela 1

Taxas de Sucesso em Adins

\begin{tabular}{l|c|c|c|c|c}
\hline \multirow{2}{*}{ Liminar } & \multicolumn{5}{|c}{ Mérito } \\
\cline { 2 - 6 } & Procedente & $\begin{array}{c}\text { Procedente } \\
\text { em Parte }\end{array}$ & $\begin{array}{c}\text { Improce- } \\
\text { dente }\end{array}$ & Não Julgado & Total \\
\hline Deferido & 4 & - & 33 & 20 & 57 \\
Deferido em parte & 18 & 2 & 46 & 31 & $\mathbf{9 7}$ \\
Indeferido & 10 & 13 & 416 & 40 & $\mathbf{4 7 9}$ \\
Não incluiu pedido & 1 & 5 & 14 & 11 & 31 \\
Não julgado & - & - & 6 & 242 & $\mathbf{2 4 8}$ \\
\hline Total & 33 & $\mathbf{2 0}$ & $\mathbf{5 1 5}$ & $\mathbf{3 4 4}$ & $\mathbf{9 1 2}$ \\
\hline
\end{tabular}

Total de Adins que implicaram alguma mudança na legislação contestada (células coloridas)

Porcentagem do total de Adins contra leis federais que implicaram alguma mudança

Porcentagem do total de Adins contra leis federais já julgadas que implicaram mudança

Elaboração dos autores.

Dados oriundos de http://www.stf.gov.br.

2. Todavia, devemos frisar que a importância política do tribunal não se restringe aos casos em que ele efetivamente declara inconstitucionais trechos de leis ou mesmo estatutos legais inteiros. O simples acionamento da corte por partidos oposicionistas e por diferentes grupos de interesse possui um significado que extrapola o posicionamento finalmente firmado pela corte nesses contextos. O uso das Adins para desmerecer e declarar oposição a certas políticas públicas, por exemplo, não necessita de decisões que impliquem alteração legislativa para que se atinjam esses resultados. Nesse sentido, vale ressaltar que, além de as Adins serem um instrumento convenientemente mensurável (ao contrário da maioria dos processos nos tribunais de primeira instância, por exemplo), elas tendem a acompanhar os padrões mais gerais de judicialização da política: embora existam estratégias de uso diferenciado dos tribunais inferiores, o conteúdo dos processos usados em tais estratégias muitas vezes acaba chegando ao STF, inclusive por meio de Adins que são ajuizadas enquanto esses processos correm junto às instâncias inferiores do Poder Judiciário ${ }^{4}$. Como as Adins 
apresentam baixo custo e elevada repercussão, os atores tendem a utilizá-las para garantir a visibilidade de sua ação política.

Passemos à análise dos dados compilados para esta pesquisa.

\section{Análise Descritiva}

Nesta seção, descrevemos algumas diferenças na utilização das Adins entre os governos Fernando Henrique Cardoso e Luiz Inácio Lula da Silva. A primeira grande diferença pode ser observada de imediato na Figura 1: como se pode ver, o uso das Adins caiu abruptamente de um período para outro, tendo 637 ações sido apresentadas nos dois mandatos de Fernando Henrique e um número quase $60 \%$ menor, 275, nos primeiros cinco anos e quatro meses do governo Lula. Devemos ressaltar, contudo, que essa comparação não é perfeita: como se observa, ainda faltam 32 meses do segundo mandato do governo Lula para serem incorporados a nosso banco de dados. Nas taxas atuais, esses meses restantes representarão um incremento de aproximadamente $50 \%$ no número de Adins nos dois mandatos do presidente. Mesmo com tal correção, no entanto, o governo Fernando Henrique terá enfrentado mais de uma vez e meia de Adins contra sua legislação (61\%-39\%).

Figura 1

Alvo das Adins

(janeiro/1995-abril/2008)

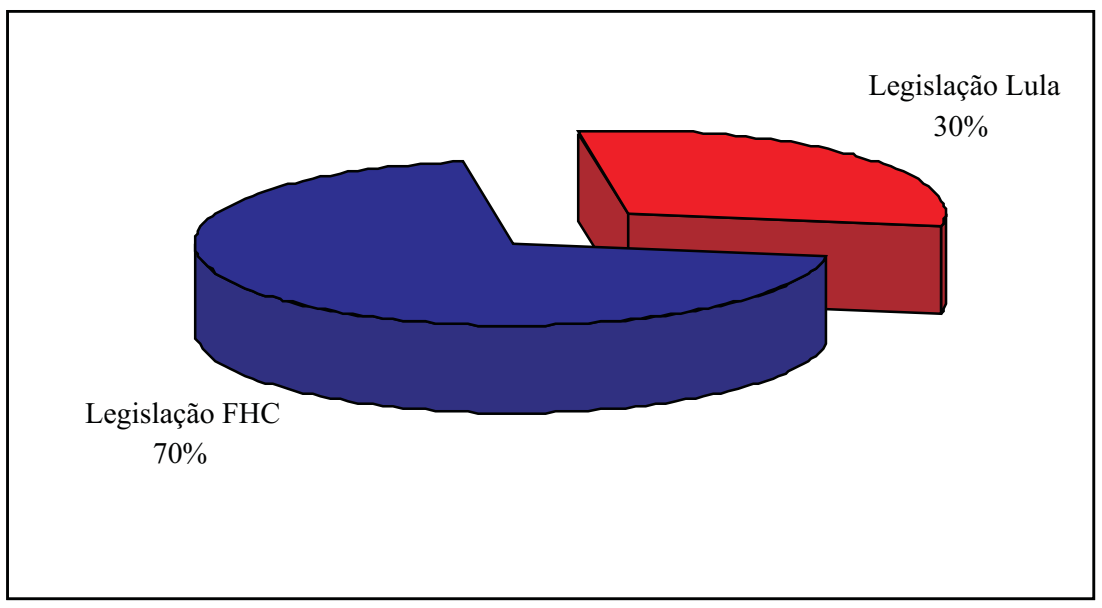

Elaboração dos autores. 
Outro dado importante a ser observado é que praticamente todos os requerentes diminuíram sua intensidade no uso das Adins após a mudança do governo Fernando Henrique para o governo Lula. Como explicar esse decréscimo? Três hipóteses podem ser levantadas. Em primeiro lugar, é possível aventar que tenha ocorrido alguma mudança institucional que explicaria a queda. Segundo, pode-se sugerir que a oposição tenha alterado suas estratégias judiciais. Por fim, pode ter ocorrido uma mudança na saliência das políticas públicas para a oposição. Nesse caso, diante do continuísmo que o governo Lula representou em algumas políticas públicas (notadamente no campo da política econômica), não haveria necessidade de contestar judicialmente suas políticas. Retomaremos essas hipóteses adiante; por ora, observemos outros dados relevantes.

Gráfico 1

Requerentes em Adins contra Normas Federais (\% em cada governo)

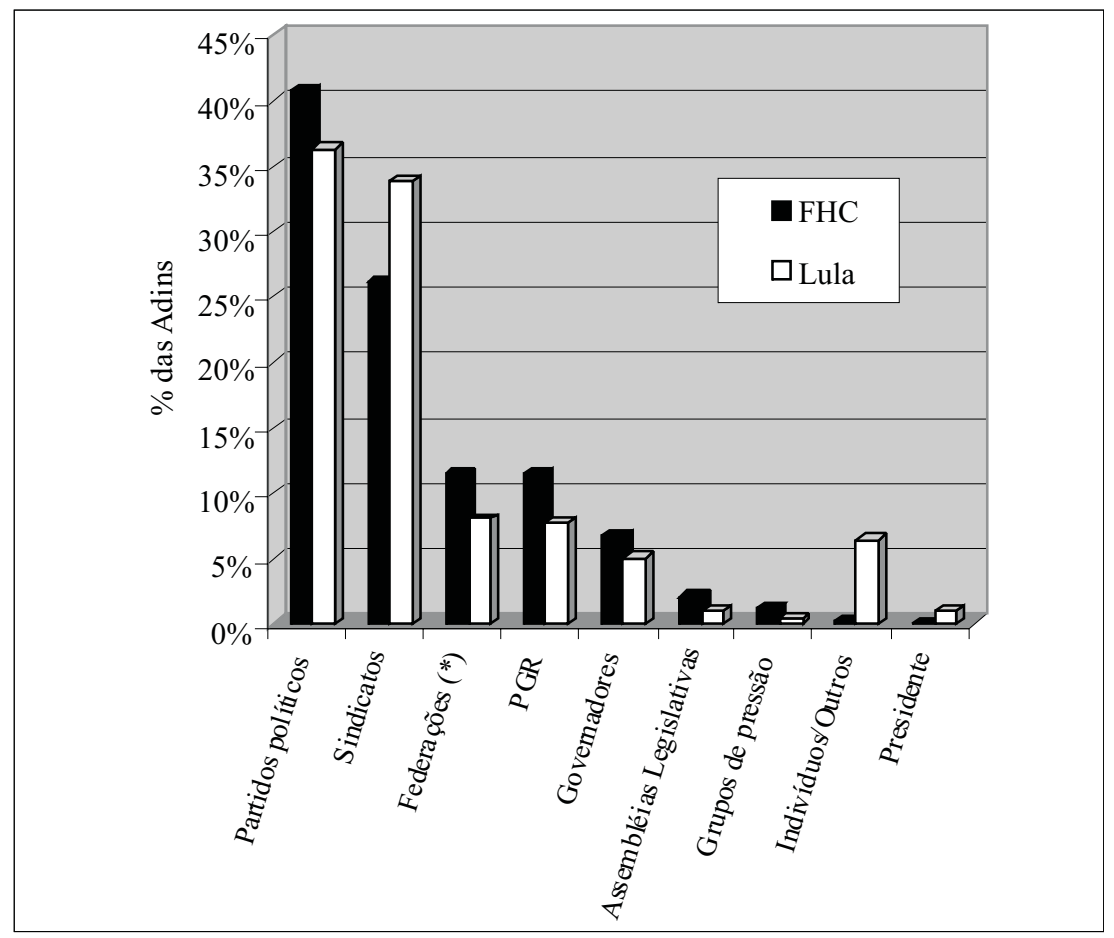

Elaboração dos autores.

${ }^{*}$ ) As federações são tanto industriais quanto comerciais. 
O Gráfico 1, ao apresentar os percentuais sobre o total correspondente a cada tipo de proponente em cada governo, permite-nos ver quatro padrões de comportamento importantes em termos comparativos entre os dois períodos analisados. Ao contrário do que se esperaria, dada a estreita relação histórica entre o Partido dos Trabalhadores - PT e o sindicalismo, houve curiosamente um aumento relativo na utilização das Adins por sindicatos. Isso pode ser atribuído ao incremento na participação de entidades ligadas ao universo jurídico, questionando aspectos da Reforma do Judiciário ${ }^{5}$, e também ao fato de os partidos políticos que representavam judicialmente os sindicatos estarem agora no governo, não podendo assim exercer mais esse papel junto ao STF. Segundo, embora não sejam legitimados ativos, houve um aumento significativo no uso de Adins por indivíduos. Nesse caso, trata-se principalmente de vereadores contestando leis eleitorais, sem nenhuma chance de conseguirem ser ouvidos pelo STF, em função de sua manifesta ilegitimidade ativa. Um terceiro ponto é a curiosa presença do próprio presidente como requerente durante o governo Lula. O quarto e último ponto é que, apesar de ter ocorrido uma redução absoluta no número de Adins, os partidos continuam sendo os principais requerentes, representando quase dois quintos de todas as Adins propostas contra normas federais, embora no período Lula praticamente compartilhem a liderança com os sindicatos.

Em relação especialmente aos partidos políticos, no Gráfico 2, pode-se constatar que os partidos requerentes tendem, em sua maioria, a ser da oposição. Para elaborar esse gráfico, usamos a participação ou não nos ministérios na época de aprovação da legislação contestada. Esse critério segue os raciocínios de Taylor (2008:104-105) e Da Ros (2008:119122 ), segundo os quais a ideologia não é o melhor indicador para prever a contestação das leis por Adin, e a participação no governo explica quase integralmente essa dinâmica. O Gráfico 2, no entanto, difere de Taylor (2008) por considerar todas as normas federais, e não somente aquelas de autoria do Poder Executivo federal. Usando esse universo, descobre-se o intrigante fato de que há uma quantidade não-irrisória de casos (7,5\% do total; dezessete Adins contra leis do governo Fernando Henrique $^{6}$ e dez contra o governo Lula) em que membros da coalizão governista utilizaram o STF para contestar atos federais. Trataremos dessa dinâmica mais adiante.

Finalmente, no Gráfico 3, analisamos o assunto das políticas públicas contestadas em Adins contra normas federais. A categorização dos tó- 
Gráfico 2

Posição Governista dos Partidos Políticos Requerentes

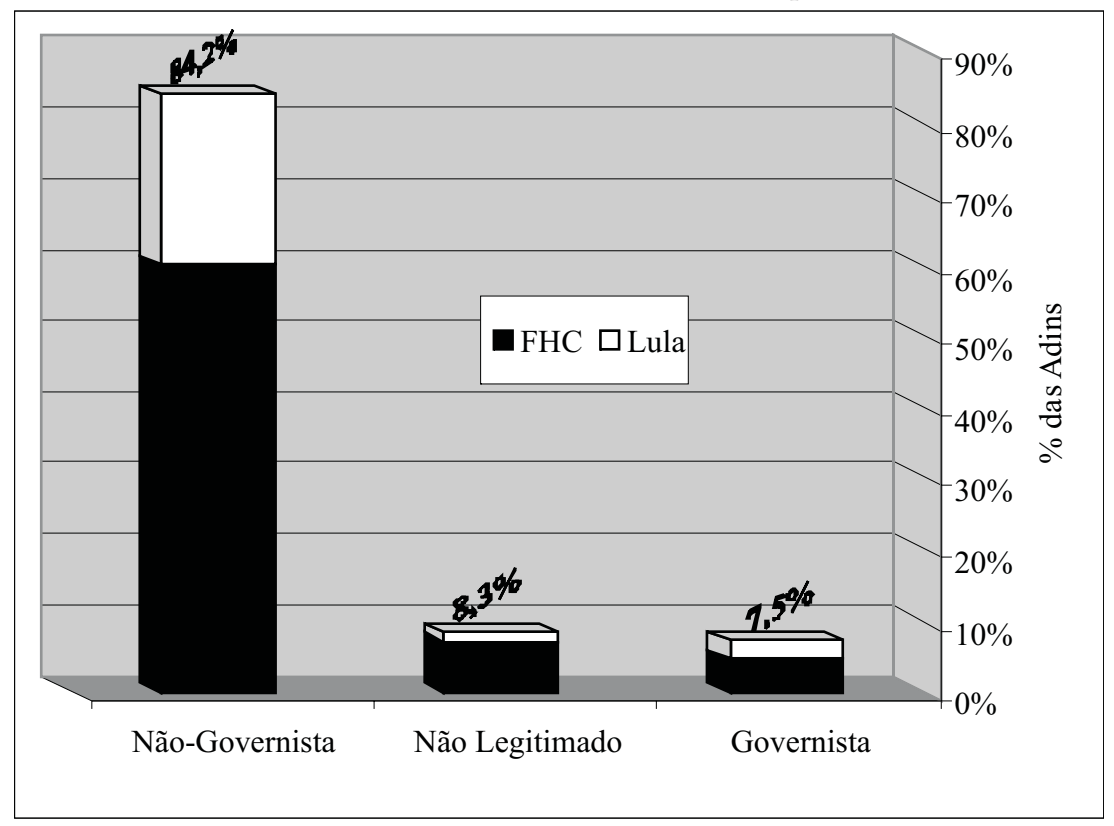

Elaboração dos autores.

Dados sobre partidos representados no ministério provenientes de Octavio Amorim Neto. Dados sobre representação no Congresso (necessários para os partidos serem considerados requerentes legitimados) acessados em 14 de maio de 2008, em http:/ / jaironicolau.iuperj.br.

picos, de nossa elaboração, baseia-se prioritariamente na análise da legislação contestada em cada ação. Alguns assuntos, como política econômica e regras previdenciárias, continuam sendo foco de muita contestação. $\mathrm{O}$ que se vê, no entanto, é uma inversão de posições: por exemplo, em vez de o PT estar reclamando contra a reforma da previdência, como fizera durante a administração tucana, agora é a própria reforma da previdência do governo petista que está sendo contestada. Em cinco outras áreas, pode-se constatar considerável diferença relativa entre os dois períodos: i) o aumento relativo no tópico Judiciário, que pode ser atribuído em grande parte à chamada "reforma do Poder Judiciário", que resultou da aprovação da Emenda Constitucional no 45, em dezembro de 2004; ii) a diminuição do assunto Servidor Público, que provavelmente pode ser explicada por uma redução no ritmo de reformas nesse sentido, além da existência de tradicional aliança entre muitos sindicatos de servidores e partidos de esquerda, notadamente o PT; iii) o aumento relativo do assunto Eleitoral, em parte resultado de mudanças na legislação que regula as eleições, mas fruto especialmente 
Gráfico 3

Assuntos Contestados em Adins Contra Normas Federais

(\% em cada governo)

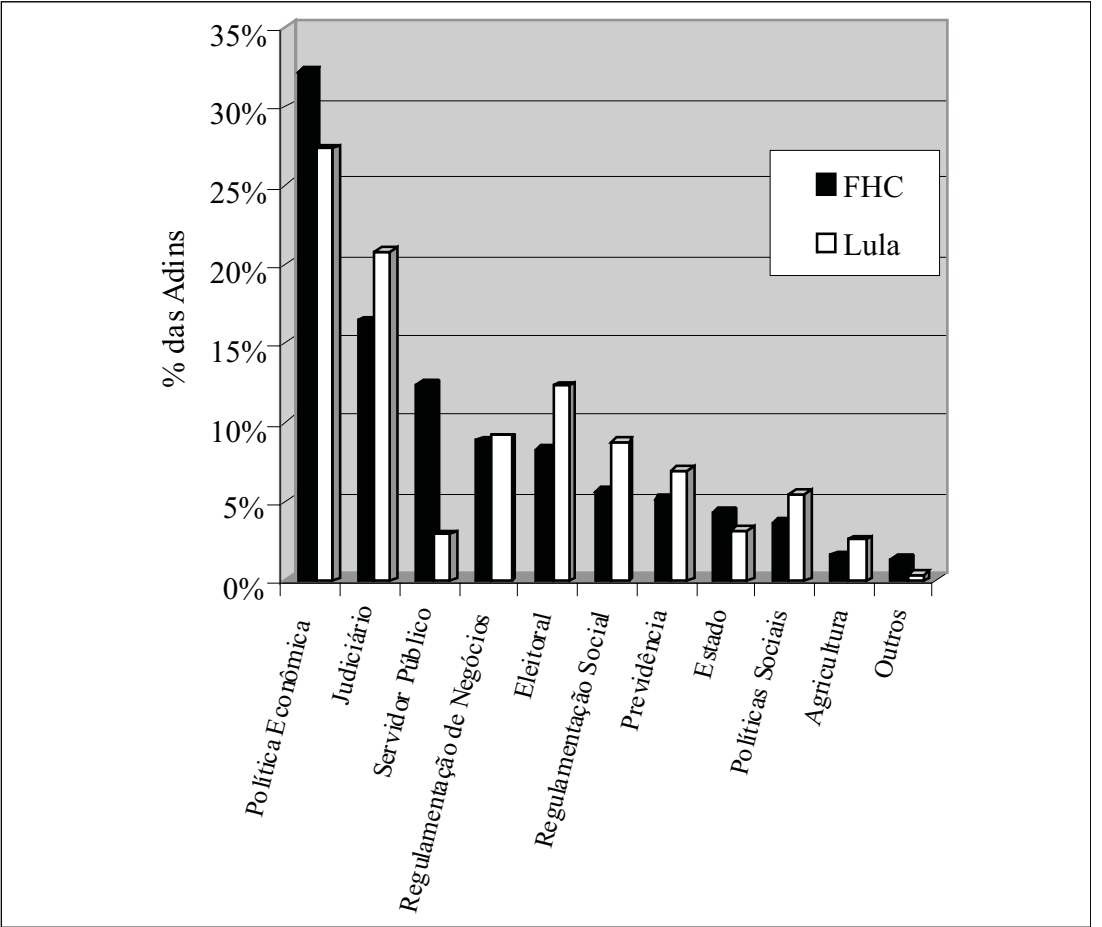

Elaboração dos autores.

de uma seqüência de decisões sobre o processo eleitoral tomadas pelo Tribunal Superior Eleitoral - TSE em anos recentes; iv) um leve incremento relativo na importância do assunto Agricultura, que ganhou saliência dentro da coalizão lulista (com destaque para Adins ajuizadas pelo Partido Verde - PV, partido integrante da base de apoio do governo) em relação a algumas decisões relativas ao plantio e à comercialização de soja geneticamente modificada; v) tanto nas áreas de Regulamentação Social quanto nas de Políticas Sociais, o aumento que se observa é causado por alguns assuntos pontuais, como leis dirigidas ao registro e à comercialização de armas de fogo e munições, práticas reguladas no Estatuto do Desarmamento e objeto de referendo durante o governo, além de outros programas governamentais novos na área social, como o ProUni - Programa Universidade para Todos, que distribui benefícios a estudantes universitários, entre outros. 
Como forma de aprofundamento, julgamos conveniente integrar à análise quantitativa a apresentação de alguns casos especialmente proeminentes na contestação judicial de políticas e decisões dos órgãos integrantes dos três Poderes do Estado na esfera federal. A fim de evitar problemas decorrentes de bias na seleção dos casos expostos, mapeamos os estatutos legais mais atacados por meio de Adins nos dois governos, localizando-os em meio a que temas gerais se inserem, respectivamente. O resultado desse cruzamento de informações mostrando os temas mais contestados via Adin - pode ser observado na Figura 2.

Inicialmente, nosso objetivo era realizar estudos de caso pormenorizados com todos os estatutos legais mais contestados judicialmente em cada governo. Todavia, em virtude do espaço exíguo, optamos por apresentar de forma mais detalhada os casos expostos na figura a seguir apenas no Apêndice deste estudo, no final do texto. Por ora, valemo-nos dessas experiências para, em conjunto com os dados quantitativos até agora expostos, tecermos conclusões a respeito das diferenças e das semelhanças nos padrões de judicialização da política verificados durante os governos Fernando Henrique e Lula, respectivamente.

Figura 2

Os Estatutos Legais mais Contestados em cada Governo

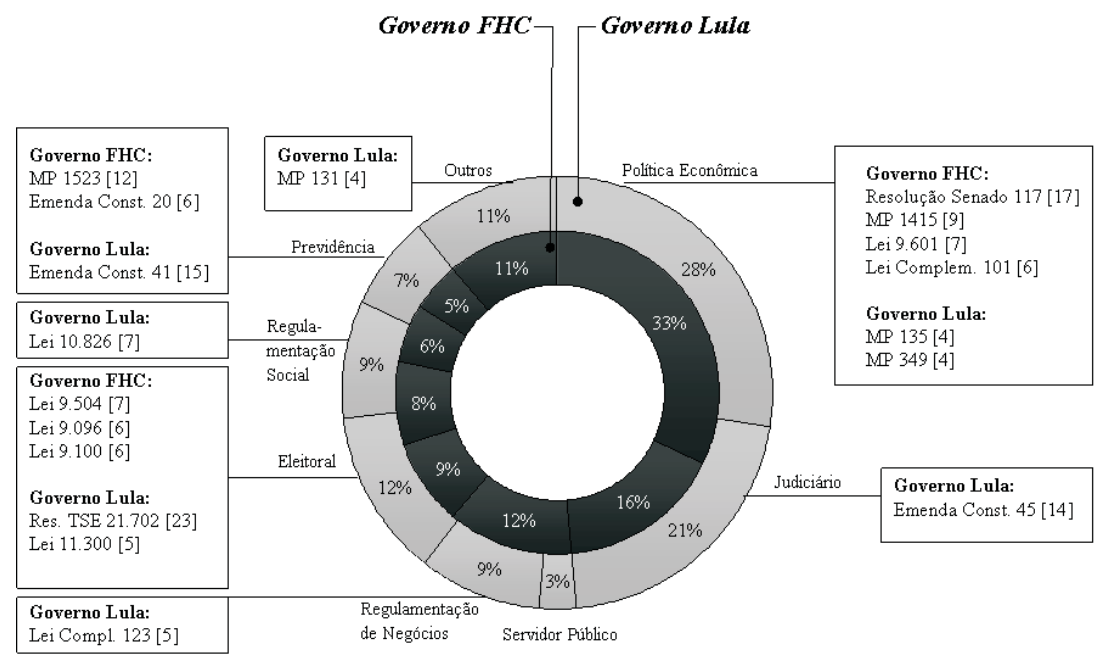

Elaboração dos autores.

Nota: Os números entre colchetes indicam a quantidade total de Adins apresentadas contra cada estatuto legal. Mostramos somente os nove estatutos legais mais contestados de cada governo, já que há um empate múltiplo para décimo lugar nos dois casos. 


\section{Semelhanças e Diferenças nos Usos da Judicialização entre os Dois Governos}

Do ponto de vista das semelhanças nos usos políticos da via judicial, acreditamos que há dois aspectos comuns a ambos os períodos. Trata-se dos diferentes tipos de argumento desenvolvidos pelos mais variados proponentes com o objetivo de judicializar determinadas políticas públicas, naquilo que doravante designaremos usos da judicialização. Essas verdadeiras retóricas da judicialização, ou conjuntos de justificativas para submeter aos tribunais (o STF, no caso) a apreciação de determinadas políticas, se articulam em dois tipos iniciais básicos, correspondentes a duas semelhanças que encontramos nos usos políticos das Adins tanto na gestão de Fernando Henrique quanto no governo Lula ${ }^{7}$.

1. Primeiramente, apresentamos o uso político mais comum da via judicial. Por motivos óbvios, trata-se daquele mais intensamente estudado pelos acadêmicos e geralmente mais noticiado pelos meios de comunicação. É aquilo que denominamos judicialização como tática de oposição. Nesse caso, os tribunais são acionados com o propósito de declarar oposição ou desmerecer políticas públicas adotadas pelo governo. Enquadram-se nesse perfil especialmente as Adins propostas por partidos políticos excluídos da coalizão governista, que são empregadas como instrumentos que amplificam a voz desses mesmos grupos no embate político. Por motivo semelhante, é de se supor que sindicatos, objetivando prestar contas a seus filiados, se valham dessas ações buscando denunciar o que consideram ser práticas equivocadas dos diferentes governos, em especial se estas atingirem direta ou indiretamente interesses da parte daqueles.

Nesse mesmo sentido, as cortes também podem ser buscadas com o objetivo de vetar integralmente ou retardar a implementação de determinadas políticas governamentais, ocasião em que o objeto a ser atacado não é necessariamente uma política pública em si, mas a simples possibilidade de impor uma derrota ao adversário. Em todos os casos, trata-se de empregar os tribunais, literalmente, como uma última instância, à qual se pode recorrer para derrotar determinadas políticas, denunciar as práticas do governo e tornar clara a posição contrária de determinados grupos a estas. Vale notar ainda que a tática judicial da oposição se integra ao panorama mais amplo das diferentes táticas que os partidos e grupos de oposição utilizam para fazer frente às políticas 
que lhes desagradam no governo em questão, como a ameaça de obstrução a determinadas votações no Congresso Nacional, no caso de partidos políticos, e manifestações públicas, em se tratando de sindicatos e outros grupos de interesses. Por essa razão, portanto, o mapeamento da intensidade do acionamento do STF pelos partidos de oposição pode ser utilizado para futuras pesquisas dos cientistas políticos brasileiros - inclusive daqueles dedicados à análise das relações entre os Poderes Executivo e Legislativo - como um indicador de polarização política, dado difícil de ser apreendido e quantificado na maior parte das vezes.

Um exemplo bastante freqüente desse tipo de uso da via judicial é dado pelas Adins propostas contra medidas provisórias - MPs, visto que estas geralmente consubstanciam os interesses imediatos do governo, muitas vezes alterando políticas de elevada repercussão. As ações judiciais apresentadas contra as cinco MPs expostas na Figura 2 se enquadram claramente nesse tipo de uso da via judicial por seus conteúdos controversos e polêmicos, como a fixação do salário mínimo (MP no 1.415), a alteração de critérios para o recebimento de diferentes benefícios previdenciários (MP no 1.523), a regulamentação do plantio e da comercialização de soja geneticamente modificada (MP no 131), e de tributos, como a Contribuição para o Financiamento da Seguridade Social - Cofins (MP no 135), além do manejo dos recursos do Fundo de Garantia do Tempo de Serviço - FGTS (MP no 349).

Todavia, o uso opositor às políticas do governo não se exaure nos casos em que os instrumentos legislativos contestados são medidas provisórias. Pelo menos uma Emenda Constitucional, a de no 41, aprovada pelo governo Lula no final de 2003, estabelecendo a chamada "reforma da previdência" e instituindo, entre outras, a contribuição dos servidores inativos, foi contestada judicialmente com propósitos abertamente oposicionistas. O mesmo se deu com pelo menos uma Lei Ordinária, a de no 9.601, de janeiro de 1998, que instituiu regras relativas à livre negociação entre empregadores e empregados contratados em regime temporário, flexibilizando, portanto, parte das relações entre capital e trabalho.

Com efeito, um elemento comum aos proponentes de todas essas ações, como parece claro, é o fato de que entre eles estão muitos partidos políticos, de diferentes pontos do espectro ideológico, mas invariavelmente na mesma posição em relação ao governo: em franca opo- 
sição. É por essa razão, por exemplo, que PT, Partido Democrático Trabalhista - PDT, Partido Comunista do Brasil - PC do B e Partido Socialista Brasileiro - PSB estiveram entre os principais proponentes de Adins contra atos do governo Fernando Henrique; e Partido da Frente Liberal/Partido Democrata - PFL/DEM, Partido da Social Democracia Brasileira - PSDB e, em menor medida, Partido Popular Socialista PPS e PDT vêm contribuindo para o ajuizamento de ações contra a gestão de Lula. Sindicatos de trabalhadores, nas duas gestões examinadas, também têm contribuído nesse sentido, declarando pública e judicialmente sua oposição a determinadas políticas dos dois governos, em uma atitude que extrapola a simples apresentação de uma queixa ao STF, mas que se utiliza do acesso ao tribunal para obter visibilidade de suas ações junto ao público.

2. O segundo tipo, que designamos judicialização como arbitragem de interesses em conflito, é talvez ainda mais freqüente. Nesse caso, não se trata tanto de fazer uso dos tribunais como instrumentos de oposição ao governo, mas sim de propor ações nos casos em que determinados estatutos legais modifiquem procedimentos e atinjam diretamente interesses de grupos e setores específicos, prejudicando alguns e beneficiando outros. Busca-se o STF com o propósito, ainda que não necessariamente declarado e imediato, de definir ou aperfeiçoar determinadas "regras do jogo". A judicialização, nesse caso, não pretende desmerecer a política pública adotada, mas sim alcançar regras procedimentais que beneficiem um determinado ator ou um conjunto deles.

Esse é claramente o caso da contestação judicial de regras que redistribuam poderes e atribuições entre diferentes entidades e instituições, como partidos políticos, entes federativos e diferentes instâncias do Poder Judiciário. Nessa perspectiva, insere-se, por exemplo, praticamente toda a contestação de regras eleitorais, das leis no 9.096, 9.100, 9.504 e 11.300, além da Resolução no 21.702, do TSE. Na maior parte dos casos, trata-se de estatutos legais que redistribuem o tempo de duração do horário eleitoral gratuito em rádio e televisão, instituem regras para o exercício da propaganda partidária, fixam prazos e limites para o registro de candidaturas e estabelecem o próprio número de cargos em disputa. Por concretamente privilegiarem determinados partidos em prejuízo de outros, não se trata de puro uso da arena judicial como extensão da política de oposição ao governo, mas da busca por uma arena em que se possa evitar que certas regras prejudiquem de forma direta alguns partidos. Nesse mesmo sentido, inclui-se, portanto, a 
contestação de regras que envolvam a redistribuição de responsabilidades e atribuições entre as entidades federativas ou que imponham limites à atuação destas. São os casos, por exemplo, da Resolução no 117, de 1997, do Senado Federal, que dispôs sobre a destinação de recursos dos estados oriundos de privatizações, e da Lei Complementar no 101, conhecida como Lei de Responsabilidade Fiscal, que limitou a destinação de recursos públicos a certas áreas pelos Estados e pela União. Há ainda dois casos que, embora não sejam estatutos legais que diretamente redefinam as relações federativas, acabam se refletindo sobre elas e, em função disso, ensejando o acionamento do STF para que ele resolva essas disputas. Isso é o que ocorre com a Lei Complementar $\mathrm{n}$ 123, de dezembro de 2006, que instituiu o Estatuto Nacional da Microempresa e da Empresa de Pequeno Porte (o chamado Simples Nacional), e pôs sob a alçada de órgãos da União a gestão, a aplicação de normas e a solução de controvérsias decorrentes da implementação desse novo regime tributário para as empresas de pequeno porte. Por causa dessa redefinição de funções, complementar ao objetivo central do estatuto legal em questão, surgiram demandas de representantes de funcionários de órgãos estaduais que buscavam ver sob sua jurisdição tais funções. Em alguma medida e um tanto paradoxalmente, trata-se também do que ocorreu com a aprovação da Emenda Constitucional no 20, de 1998, que consubstanciou a "reforma da previdência" do governo Fernando Henrique. O curioso é que, embora ela tenha apresentado um conjunto bastante controverso de medidas, apenas uma ação foi ajuizada com o propósito específico de declarar-lhe oposição (trata-se da Adin no 1.946). As outras cinco ações, contudo, foram propostas apenas meses mais tarde e se dirigiam contra limitações ao tempo de permanência dos juízes nos tribunais e contra a fixação de limites aos sistemas previdenciários estaduais, sendo quase sempre apresentadas por grupos de interesses e entidades estaduais, como assembléias legislativas ou governadores de Estados, motivos pelos quais o tipo de contestação promovido contra esse estatuto legal foi enquadrado entre aqueles que ensejam judicialização como arbitragem de interesses em conflito.

Nesse mesmo conjunto, pode ainda ser catalogado o número substantivo de Adins propostas contra a Emenda Constitucional no 45, a chamada "reforma do Judiciário", que redefiniu funções da Justiça Federal, da Justiça do Trabalho e ainda criou órgãos como o Conselho Nacional de Justiça - CNJ e o Conselho Nacional do Ministério Público CNMP, ambos com o poder de disciplinar as respectivas instituições 
que encabeçam. Como se trata fundamentalmente da batalha pela redefinição de posições internamente às profissões jurídicas, preferimos catalogá-las neste grupo.

Como se observa, tendo em vista nossa tipologia dos estatutos legais citados na Figura 2, apenas a Lei no 10.826 , de dezembro de 2003, fica de fora, sendo ela na realidade uma espécie de tipo misto, congregando categorias dos dois tipos de uso da via judicial citados anteriormente ${ }^{8}$.

3. A análise comparativa dos dois governos revela um uso político das Adins praticamente inexistente durante o governo Fernando Henrique e que passou a se fazer existente, mesmo de forma relativamente tímida, durante a gestão de Lula. Mais do que apontar outra semelhança entre os padrões de judicialização da política dos dois governos, trata-se de indicar um terceiro tipo de uso da via judicial decorrente das diferenças entre os dois períodos e que deve ser somado aos dois outros citados anteriormente para que as possibilidades de interesses que levam ao acionamento do STF e dos órgãos de cúpula do Poder Judiciário em geral sejam apreendidas de forma integral. Apresentamos, portanto, o que podemos designar judicialização como instrumento de governo. Inspirados nas lições de Whittington $(2005 ; 2007)$ sobre parte importante da atuação da Suprema Corte dos Estados Unidos, são os casos em que se busca a "mão amiga" da instituição máxima do Poder Judiciário para que esta implemente ou se pronuncie de forma favorável a políticas públicas de interesse do próprio governo.

Nesse caso, o órgão de cúpula da magistratura pode ser buscado tanto para superar situações de paralisia decisória ou de impasse legislativo (gridlock) que os juízes resolvem favoravelmente ao governo quanto, de forma direta, para que se anulem estatutos legais que os integrantes da administração governista busquem retirar do ordenamento jurídico. Aqueles podem ser tanto leis emitidas por governos passados que os atuais busquem atacar, eventualmente "corrigindo" erros políticos de administrações ideologicamente distintas do passado, quanto estatutos legais de autoria de outros órgãos que não diretamente sob responsabilidade do Poder Executivo, como resoluções de Casas legislativas e de tribunais, ou ainda projetos que esses aprovaram à revelia do governo. Devemos frisar, contudo, que esse uso político das cortes também pode ser empregado, a exemplo do que fazem os partidos oposicionistas, para que o governo declare sua oposição a determinadas medidas, eventualmente impopulares, tomadas por Casas legisla- 
tivas ou tribunais, especialmente referentes ao aumento dos próprios salários ou de seus gastos com pessoal, entre outros. Esse é claramente o caso, por exemplo, de Adins propostas pelo próprio presidente da República, como as de no 3.599, 3.785 e 3.834, apresentadas respectivamente contra as leis no 11.169 e 11.170 (que alteravam a remuneração de servidores da Câmara dos Deputados e do Senado Federal), contra a Resolução Administrativa no 98 do Tribunal Regional do Trabalho TRT da 18a Região (que incorporava gratificações à aposentadoria dos magistrados integrantes do Tribunal), e contra a Resolução no 9, do Conselho Nacional do Ministério Público (que também incorporava gratificações às aposentadorias dos membros do Ministério Público). Por outro lado, um exemplo de tentativa de correção daquilo que o governo corrente considera um erro político do passado pode ser dado pela Adin no 3.578, proposta contra trechos da Lei no 9.491, de 1997, que dispõe sobre o Programa Nacional de Desestatização. Apresentada pelo PC do B em 2005, quando o partido integrava a coalizão do governo Lula, seu propósito era declarar inconstitucionais trechos da lei referentes ao rol de bens, empresas e serviços que o Estado pode inserir na política de privatizações. O objetivo dos proponentes era reduzir esse leque, como foi efetivamente conseguido pela concessão da liminar.

\section{Explicando as Principais Diferenças na Judicialização entre os Dois Governos}

Uma vez expostas duas semelhanças e uma pequena diferença quanto aos usos da judicialização entre os governos analisados, acreditamos estar aptos a discorrer sobre as possíveis explicações para as principais diferenças encontradas na comparação apresentada anteriormente. Como afirmamos no início deste texto, há basicamente três hipóteses que podem explicar a queda praticamente geral no acionamento do mais alto tribunal do país em face das normas de autoria de órgãos integrantes da esfera federal.

1. A primeira hipótese dá conta de identificar a ocorrência de uma possível mudança institucional entre um governo e outro, ou no período próximo à troca entre gestões, que ensejasse semelhante decréscimo no acionamento da corte. Ainda que não tenha sido objeto de estudo da parte dos cientistas políticos, os efeitos disciplinadores possivelmente advindos da aprovação da Lei no 9.868, de 10 de novembro de 1998, que se fizeram sentir de modo efetivo apenas a partir de 1999, devem ser 
analisados nesta pesquisa mesmo que de forma sumária. Fruto da iniciativa legislativa do Poder Executivo, tal lei regulamenta, entre outros fatores, a concessão de liminares pelo STF em sede de Adins, impondo-lhe um rito mais rigoroso que o anteriormente existente, o que aponta inclusive certo disciplinamento da corte pelos demais Poderes do Estado. A referida lei estipula que a concessão de liminares em Adins seja realizada apenas pela maioria absoluta dos membros da corte em sessão com pelo menos oito ministros, salvo nos períodos de recesso. A idéia, ao que parece, visava dar fim à prática de concessão de liminares por decisões monocráticas ad referendum e também evitar decisões duplas, contraditórias entre si, uma no julgamento da liminar e outra no julgamento de mérito. Dessa forma, passaram a priorizar as decisões finais do STF, consubstanciadas no pronunciamento de mérito da ação, que leva mais tempo para se atingir, dificultando, portanto, as chances de intervenção da corte. Em virtude desse regime mais rígido para concessão de liminares, é possível supor que, em parte, a eventual queda no acionamento do STF entre os dois períodos analisados se deva também à perspectiva conferida por essa lei de menores chances de deferimento na decisão liminar e até mesmo naquela de mérito. Como essa lei possivelmente reduziu as chances de concessão de liminares em Adins, pode-se supor que os partidos se tenham interessado menos no uso desse instrumento, fato que pode ter contribuído para a eventual queda na contestação judicial junto ao STF.

Embora plausível em uma análise inicial, acreditamos que essa hipótese contribui muito pouco para explicar a variação observada. Isso ocorre por duas razões básicas: em primeiro lugar, como frisamos, a maioria dos proponentes (especialmente os partidários) recorre aos tribunais não tanto com a intenção de ver a lei atacada na Adin ser efetivamente declarada inconstitucional, mas fundamentalmente porque pretende se valer da via judicial como um canal para garantir mais visibilidade a seus atos contrários ao governo, tornando mais públicas suas declarações de oposição a políticas adotadas pelo governo ou ao governo propriamente. Portanto, como não há uma preocupação efetiva em invalidar a lei na maioria dos casos, a maior ou menor chance na concessão de liminar não integra o cálculo dos oposicionistas, sendo praticamente irrelevante nesse sentido. Em segundo lugar, mesmo que essa probabilidade na concessão das liminares se tenha reduzido, como o tribunal é a última instância à qual se pode recorrer para tentar derrotar uma lei e o custo no acionamento continua idêntico ao anteriormente existente (baixo, portanto), não há por que supor que os pro- 
ponentes, todos nesse caso, levem em conta a chance de sucesso na hora de pensar em propor ou não uma Adin'. Como seu custo é diminuto e o tribunal é a última possibilidade de se derrotar determinada lei, as chances de vitória na liminar, novamente, não são essenciais ao cálculo sobre o acionamento do tribunal, motivo pelo qual acreditamos que essa lei não tenha influência sobre a intensidade no acionamento da corte ${ }^{10}$.

2. Uma segunda hipótese está centrada nas diferenças dos atores em cada momento. Ao contrário da anterior, essa hipótese nos parece mais robusta. Isso porque é de se supor que o tipo de estratégia judicial esteja ligado ao tipo de estratégia oposicionista, mais amplo, adotado especialmente pelos partidos políticos. No caso do PT, enquanto o partido se encontrava na oposição, a estratégia política mais ampla constituía-se de fazer oposição sistemática ao governo, incrementando ao máximo o custo e os riscos da atividade governativa, motivo pelo qual o uso das Adins foi mais intenso. Nos casos de PSDB e PFL/DEM, quando passaram à oposição, a estratégia política mais ampla parece ter sido a de oposição seletiva, inclusive como anunciado em princípios do governo Lula pelos próprios partidos oposicionistas ${ }^{11}$. Como isso se refletiria também na contestação judicial das políticas governamentais, seria de se esperar justamente a diminuição no ritmo do uso das Adins.

Por outro lado, devemos lembrar que há "fogo amigo" em ambos os governos, mas sua intensidade é bastante mais elevada no governo Lula. Por "fogo amigo", entenda-se a contestação de políticas majoritárias pelos próprios partidos integrantes da coalizão governista. As dificuldades de manutenção da disciplina da base pelo governo Lula se refletiram inclusive na arena judicial, com partidos como PDT, Partido Trabalhista Brasileiro - PTB e PV ajuizando Adins no período pós-2003. Vale ressaltar que a rigidez da disciplina do governo Fernando Henrique não o impediu de ver ajuizada contra si pelo menos uma ação. Foi o caso da Adin no 1.636, proposta em 1997 pelo Partido Progressista Brasileiro - PPB - ex-Partido Progressista Reformador - PPR e atual Partido Progressista - PP, que entrara na coalizão governista um ano antes - justamente contra a medida provisória no 1.523 , presente na Figura 2, que dispunha sobre o recebimento de benefícios por parte de segurados do sistema previdenciário. Vale lembrar que, nesse caso, o partido não rompeu com a coalizão majoritária, afastando-se desta apenas no ano de 2003, em razão da eleição presidencial ${ }^{12}$. 
3. Uma terceira hipótese baseia-se no contexto político e, em particular, na saliência das políticas públicas que foram implementadas em cada momento. Em geral, é possível argumentar que houve uma mudança no contexto político do governo Fernando Henrique para o governo Lula. Além da mudança estratégica dos principais partidos políticos apontada anteriormente, houve também uma mudança na pauta das principais políticas públicas em discussão. A maioria das políticas governamentais centrais da gestão de Lula foi sensivelmente menos controversa do que as da administração tucana, ensejando menos polêmica e dificultando as situações em que passa a ser cômodo à oposição se valer da via judicial como canal de denúncia das supostas irregularidades existentes nas medidas adotadas.

Dito de forma menos normativa, houve uma mudança na saliência das principais políticas no período, determinada sobretudo pela alocação dos custos e benefícios destas entre "ganhadores" e "perdedores". Como Taylor $(2007 ; 2008)$ aponta, as características das políticas públicas em si ajudam a determinar sua judicialização. Os trabalhos de Lowi (1964; 1972) e Wilson (1995) - sumarizados como policy determines politics - mostram que a distribuição de custos e de benefícios das políticas públicas (policy) determina os percursos de seu andamento político (politics) no Executivo e no Legislativo. Da mesma forma, Taylor (2008) argumenta que - ceteris paribus - essas características também influenciam a provável intensidade de utilização do Judiciário. Quando os custos de uma determinada política são muito concentrados em um pequeno grupo de "perdedores", é de se esperar que a judicialização seja maior, em especial se tais atores são minimamente organizados e/ou possuem quem possa representá-los para atuar na arena judicial (partidos políticos, por exemplo).

Três mudanças importantes ocorreram na pauta de políticas públicas entre os governos Fernando Henrique e Lula. A primeira é o fato de o governo petista ter se apropriado da política econômica tucana a partir da publicação da Carta ao Povo Brasileiro, em 2002, seguida pela nomeação de Henrique Meirelles e Antonio Palocci para os dois principais cargos econômicos no país. Simultaneamente, porém, houve uma mudança sensível na pauta de políticas públicas no tocante ao funcionalismo, eliminando-se um dos principais pontos de conflito e de judicialização advinda da esquerda. Finalmente, ao passo que de 1995 a 2002 a política econômica e a reforma do Estado ocuparam a agenda do governo, o que se refletiu nos temas abordados nas ações propostas, $\mathrm{o}$ 
mesmo não é inteiramente verdadeiro no período de 2003 em diante, quando as políticas distributivas ganharam destaque. Estas, todavia, por seu caráter menos controverso e mais consensual, foram menos abordadas nas ações ajuizadas. Os custos impostos por políticas distributivas são difusos e, portanto, tendem a gerar menos oposição.

Das medidas aprovadas durante a administração petista, acreditamos que apenas a reforma da previdência, consubstanciada na Emenda Constitucional no 41 , de dezembro de 2003, resguarde controvérsia semelhante à boa parte das políticas da gestão de Fernando Henrique, motivo pelo qual inclusive essa reforma foi justamente muito atacada no STF, como se pôde constatar. Em vista dessa relativa ausência de temas polêmicos, que impinjam elevados custos a determinados segmentos da sociedade, alguns assuntos de matriz setorial, como a reforma do Judiciário, a regulação da atividade agrícola e de armas de fogo, entre outros, têm sido os mais submetidos à apreciação do STF durante o governo petista.

Mais do que encarar essas duas últimas hipóteses - mais críveis do que a primeira - como duas explicações alternativas e mutuamente excludentes, acreditamos que as variações ora analisadas somente podem ser compreendidas de forma conjunta. Em grande parte, portanto, o uso conferido à via judicial pelos opositores é condicionado ao teor das políticas adotadas pelo governo - especialmente se estas apresentam custos mais ou menos concentrados em determinados grupos. Mesmo nesses casos, entretanto, a decisão pela contestação judicial dependerá não apenas das políticas consideradas em si mesmas, mas também da estratégia política que os diferentes atores adotam em relação ao governo. Como se pode observar, portanto, nem as políticas governamentais nem os oponentes, ambos considerados de forma isolada, explicam essa dinâmica, merecendo serem agregados para conferir melhor tratamento à questão.

\section{CONCLUSÃO}

Este estudo mostrou a significativa diferença no uso das Adins durante os governos Fernando Henrique Cardoso e Luiz Inácio Lula da Silva tanto em termos quantitativos quanto substantivos. Tendo em vista a ausência de mudanças institucionais que poderiam alterar os incentivos à judicialização, apontamos dois fatores alternativos que ajudam a explicar essas diferenças. Ainda que os canais institucionais importem, com efeitos especialmente visíveis em perspectiva comparada, 
devemos observar que instituições são em grande medida instrumentos políticos e dependem da efetiva utilização que deles fazem os diferentes atores. Como o uso da via judicial pelos diferentes proponentes (partidos políticos em especial) depende do teor das políticas adotadas e do respectivo ambiente conjuntural da política do momento, sua utilização somente pode ser compreendida tendo em vista a estratégia política mais ampla adotada pelos opositores do governo e a saliência das políticas públicas consideradas em determinado momento.

Por outro lado, a pesquisa também apontou certa continuidade em dois usos dados às Adins, naquilo que denominamos usos da judicialização: 1) a judicialização como tática de oposição, utilizada para retardar, impedir, desmerecer ou declarar a oposição a determinadas leis; 2) a judicialização como arbitragem de interesses em conflito, utilizada para tornar as regras do jogo mais amenas a determinado grupo de interesse. Embora a saliência das políticas públicas para a oposição ao governo Lula tenha reduzido a utilização da judicialização como tática de oposição, não a removeu completamente do leque de táticas políticas da oposição brasileira. Entre os casos mais contestados, houve também um ligeiro aumento na utilização da judicialização para arbitrar interesses, em grande parte em decorrência das mudanças institucionais referentes ao Poder Judiciário e às regras eleitorais. O estudo também aponta a emergência, mesmo que tênue, de uma terceira forma de judicialização, que denominamos 3) judicialização como instrumento de governo.

Finalmente, este artigo aponta novos caminhos a serem trilhados em pesquisas futuras. Uma integração mais coerente e consciente dos estudos sobre judicialização com a literatura sobre as relações Executivo-Legislativo no Brasil nos parece a mais promissora. Em especial, merece ser testada a hipótese de que o sistema político brasileiro é majoritário na definição das políticas públicas e consensual em sua implementação, sendo esse último determinado em boa medida pela ação do Judiciário como ponto de veto (Taylor, 2007). Isto é, o Judiciário parece oferecer um locus significativo - amplamente conhecido pelos atores políticos - para contestar as políticas públicas mesmo após sua aprovação por amplas maiorias legislativas. Até que ponto se pode comprovar essa tese agregando aos dados relativos à produção legislativa os padrões de judicialização? Nesse sentido, cabe também indagar: qual é a diferença entre o tratamento dado aos estatutos legais de caráter unilateral (MPs, decretos, resoluções e portarias) em relação às leis apro- 
vadas por maiorias e mesmo por maiorias sobredimensionadas? E ainda: qual é o impacto de toda essa interação sobre o sistema de governo de coalizão? Essas perguntas formam parte do desafio que este estudo nos coloca, e ao qual esperamos nos dedicar em outra oportunidade.

(Recebido para publicação em agosto de 2008)

(Versão definitiva em outubro de 2008)

\section{NOTAS}

1. Pretende-se incluir nessa análise outros requerentes, além de partidos políticos, uma vez que alguns foram ou ainda são aliados de alguns dos partidos políticos que integram ou integraram a coalizão governista, sendo alguns deles também representantes de importantes interesses difusos contestados ao longo dos diferentes governos. Não incluí-los no levantamento poderia ocasionar a exclusão de dados importantes, capazes de identificar fontes relevantes de contestação judicial às atividades dos governos advindas de fontes específicas que não necessariamente coincidem com os respectivos partidos opositores.

2. Embora existam algumas exceções, em quase todos os casos a legislação foi aprovada antes de a Adin ter sido proposta junto ao STF.

3. Esse segundo cálculo talvez seja menos justificável: como mostra Da Ros (2008), a demora processual às vezes é empregada estrategicamente para a tomada de decisões informais por parte do STF. A existência de muitas ações sem julgamento não indica necessariamente, portanto, que a corte futuramente vá se pronunciar a respeito de todas essas Adins. Ainda que algumas dessas ações venham a ser apreciadas pelo STF em algum momento no futuro, em grande parte, o decurso do tempo serve como uma justificativa hábil ao tribunal para não intervir diante de muitos temas.

4. Nenhum outro instrumento legal que tenha efeitos vinculantes e universais tem sido tão usado junto ao STF desde 1988. A Ação Declaratória de Constitucionalidade ADC, criada em 1993, tem sido pouco usada e por sua própria natureza pouco contribui como instrumento de oposição. Por sua vez, a Argüição de Descumprimento de Preceito Fundamental - ADPF pode ser relevante a futuras pesquisas, mas, como foi regulamentada em 1999, seus efeitos não se aplicam a todo o período ora analisado, razão pela qual preferimos não estudá-la.

5. Sobre o corporativismo das profissões no Judiciário, ver Sadek (1995).

6. Sendo que, dessas dezessete Adins, cinco foram impetradas após o término do segundo mandato de Fernando Henrique.

7. Essa classificação referente às motivações das partes não busca identificar modelos estanques de proponentes, mas antes indicar traços comuns a alguns deles que facili- 


\section{Matthew M. Taylor e Luciano Da Ros}

tem a compreensão do fenômeno. Apesar de relativamente inédita em seu propósito, ela já foi parcialmente esboçada em dois outros trabalhos (Da Ros, 2006; 2008:163-165) e agrega contribuições fornecidas pelos diversos autores que se dedicaram a estudar o STF no contexto recente de democracia brasileira (Arantes, 1997; Castro, 1997a; 1997b; Werneck Vianna et alii, 1999, entre outros), bem como achados de pesquisas sobre outras realidades nacionais (Dotan e Hofnung, 2005; Whittington, 2007:103-157).

8. Mais detalhes sobre esse caso, bem como de todos os outros expostos na Figura 2, como já mencionado, encontram-se expostos no Apêndice deste artigo, no final do texto.

9. Alguns requerentes, como a Ordem dos Advogados do Brasil-OAB, se preocupam mais do que os partidos que têm sua "reputação legal". Isso pode ajudar a explicar sua taxa de sucesso relativamente alta, além de sua relativa reticência na utilização das Adins como mero instrumento declaratório de oposição (Taylor, 2008:109-131).

10. Isso não quer dizer, entretanto, que a referida lei não tenha tornado menos prováveis as chances de o STF intervir sobre o conteúdo de determinada legislação. Na realidade, é razoável supor que isso de fato tenha ocorrido, mas sua verificação somente poderia ser efetivamente testada em outro estudo. O que buscamos apresentar aqui é apenas que essa provável diminuição nas chances de sucesso junto ao STF, em função do novo regime de concessão de liminares, não se integra ao cálculo sobre o uso político do tribunal e que, portanto, não serve como explicação para a redução no acionamento da corte na passagem do governo Fernando Henrique para a gestão de Lula.

11. Em princípios de 2003, a expressão correntemente propalada por esses partidos opositores era a de que se exerceria oposição responsável ao governo Lula. Para evitar o tom intencionalmente normativo dessa expressão, preferimos substituí-la simplesmente por oposição seletiva.

12. Semelhantemente ao que ocorre com a possibilidade do uso da intensidade no acionamento do STF pelos partidos de oposição como um indicador de polarização política, a propositura de Adins por partidos da base do governo talvez possa ser empregada como um indicador da instabilidade na disciplina da coalizão governista, especialmente do ponto de vista das pesquisas referentes às relações Executivo-Legislativo. 
Os Partidos Dentro e Fora do Poder: A Judicialização como Resultado...

\section{REFERÊNCIAS BIBLIOGRÁFICAS}

ARANTES, Rogério Bastos. (1997), Judiciário e Política no Brasil. São Paulo, Sumaré.

CARVALHO NETO, Ernani Rodrigues de. (2004), “Em Busca da Judicialização da Política: Apontamentos para uma Nova Abordagem". Revista de Sociologia e Política, no 23, pp. 115-124.

. (2005), Revisão Abstrata de Legislação e a Judicialização da Política no Brasil. Tese de doutorado em Ciência Política, Universidade de São Paulo, São Paulo.

CASTRO, Marcus Faro de. (1997a), "O Supremo Tribunal Federal e a Judicialização da Política". Revista Brasileira de Ciências Sociais, vol. 12, no 34, pp. 147-156.

. (1997b), "The Courts, Law, and Democracy in Brazil". International Social Science Journal, vol. 49, no 152, pp. 241-252.

CLAYTON, Cornell W. e GILLMAN, Howard (eds.). (1999), Supreme Court Decision-Making: New Institutionalist Approaches. Chicago, University of Chicago Press.

DA ROS, Luciano. (2006), Tribunais como Árbitros ou como Instrumentos de Oposição? Judicialização da Política em Novas Poliarquias à Luz do Caso Brasileiro. Trabalho apresentado no I Congresso Uruguaio de Ciência Política, Montevidéu, 30-31 de outubro.

(2008), Decretos Presidenciais no Banco dos Réus: Análise do Controle Abstrato de Constitucionalidade de Medidas Provisórias pelo Supremo Tribunal Federal no Brasil (1988-2007). Dissertação de mestrado em Ciência Política, Universidade Federal do Rio Grande do Sul, Porto Alegre.

. (no prelo), "Poder de Decreto e Accountability Horizontal: Dinâmica Institucional dos Três Poderes e Medidas Provisórias no Brasil Pós-1988”. Revista de Sociologia e Política.

DOTAN, Yoav e HOFNUNG, Menachem. (2005), "Legal Defeats - Political Wins: Why do Elected Representatives Go to Court?" Comparative Political Studies, vol. 38, no 1, pp. 75-103.

FIGUEIREDO, Argelina Cheibub e LIMONGI, Fernando. (1999), Executivo e Legislativo na Nova Ordem Constitucional. Rio de Janeiro, Editora FGV.

HAMILTON, Alexander. (2003) [1788], “№ 78: The Judiciary Department”, in A. Hamilton, J. Madison e J. Jay, The Federalist Papers. New York, Signet Classics, pp. 463-471.

KOERNER, Andrei e MACIEL, Débora Alves. (2002), "Sentidos da Judicialização da Política: Duas Análises". Lua Nova, no 57, pp. 113-134.

LOWI, Theodore. (1964), "American Business, Public Policy, Case-Studies, and Political Science". World Politics, vol. 16, pp. 677-715.

(1972), "Four Systems of Policy, Politics, and Choice". Public Administration Review, vol. 33, pp. 298-310.

OLIVEIRA, Fabiana Luci de. (2006), Justiça, Profissionalismo e Política: O Supremo Tribunal Federal e o Controle da Constitucionalidade das Leis no Brasil (1988-2003). Tese de doutorado em Ciências Sociais, Universidade Federal de São Carlos, São Carlos. 


\section{Matthew M. Taylor e Luciano Da Ros}

OLIVEIRA, Vanessa Elias de. (2005), “Judiciário e Privatizações no Brasil: Existe uma Judicialização da Política?" DADOS, vol. 48, no 3, pp. 559-587.

PACHECO, Cristina Carvalho. (2006), O Supremo Tribunal Federal e a Reforma do Estado: Uma Análise das Ações Diretas de Inconstitucionalidade Julgadas no Primeiro Governo de Fernando Henrique Cardoso (1995-1998). Tese de doutorado em Ciências Sociais, Universidade Estadual de Campinas, Campinas.

RÍOS-FIGUEROA, Julio e NAVIA, Patricio. (2005), “The Constitutional Adjudication Mosaic of Latin America". Comparative Political Studies, vol. 38, no 2, pp. 189-217.

RÍOS-FIGUEROA, Júlio e TAYLOR, Matthew M. (2006), “Institutional Determinants of the Judicialisation of Policy in Brazil and México". Journal of Latin American Studies, vol. 38, no 4, pp. 739-766.

SADEK, Maria Tereza. (1995), "A Organização do Poder Judiciário no Brasil”, in M. T. Sadek (org.), Uma Introdução ao Estudo da Justiça. São Paulo, Sumaré, pp. 7-63.

SMITH, Rogers. (1988), "Political Jurisprudence, the 'New Institutionalism', and the Future of Public Law". American Political Science Review, vol. 82, no 1, pp. 89-108.

TAYLOR, Matthew M. (2006), "Veto and Voice in the Courts: Policy Implications of Institutional Design in the Brazilian Judiciary". Comparative Politics, vol. 38, no 3, pp. 337-355.

(2007), “O Judiciário e as Políticas Públicas no Brasil”. DADOS, vol. 50, no 2, pp. 229-257.

. (2008), Judging Policy: Courts and Policy Reform in Democratic Brazil. Stanford, Stanford University Press.

WERNECK VIANNA, Luiz et alii. (1999), A Judicialização da Política e das Relações Sociais no Brasil. Rio de Janeiro, Revan.

WERNECK VIANNA, Luiz, BURGOS, Marcelo Baumann e SALLES, Paula Martins. (2007), “Dezessete Anos de Judicialização da Política". Tempo Social, vol. 19, no 2, pp. 39-85.

WHITTINGTON, Keith. (2005), “'Interpose your Friendly Hand': Political Supports for the Exercise of Judicial Review by the United States Supreme Court". American Political Science Review, vol. 99, no 4, pp. 583-596.

. (2007) Political Foundations of Judicial Supremacy: The Presidency, the Supreme Court, and Constitutional Leadership in U.S. History. Princeton, Princeton University Press.

WILSON, James. (1995), Political Organizations. Princeton, Princeton University Press. 


\section{APÊNDICE}

Estatutos legais mais contestados nos governos Fernando Henrique Cardoso e Luiz Inácio Lula da Silva.

\section{GOVERNO FERNANDO HENRIQUE}

Resolução n117, de 1997, do Senado Federal. Alterava o art. 13 da Resolução no 69 do Senado Federal, de 1995, obrigando os Estados, Distrito Federal - DF e Municípios a empregar no mínimo 50\% da receita havida com privatizações na amortização ou liquidação de dívidas resultantes de empréstimos obtidos junto à União, instituições financeiras nacionais ou estrangeiras, organismos internacionais, ou ainda no pagamento de precatórios judiciais, ou no pagamento de valores referentes à dívida pública mobiliária. Quem contestou a medida foram os governadores de dezessete Estados (São Paulo - SP, Rio de Janeiro - RJ, Minas Gerais - MG, Rio Grande do Sul - RS, Paraná - PR, Santa Catarina - SC, Paraíba - PB, Pará - PA, Rio Grande do Norte - RN, Goiás GO, Ceará - CE, Rondônia - RO, Espírito Santo - ES, Mato Grosso MT, Mato Grosso do Sul - MS, Piauí - PI). A liminar foi deferida de forma unânime pelo STF na primeira Adin proposta (no 1.728, do governador da PB). Meses mais tarde, em junho de 1998, o Senado Federal aprovou outra Resolução (no 78), revogando integralmente a de no 69, que fora modificada pela de no 117 , não fazendo nenhuma menção à destinação de recursos oriundos de privatizações. Adins: 1.728, 1.733, 1.734, 1.735, 1.736, 1.737, 1.738, 1.739, 1.740, 1.741, 1.742, 1.743, 1.744, $1.745,1.761,1.769,1.796$. Resultado do julgamento: vitória dos governadores.

Medida Provisória n-1.523, de 12 de outubro de 1996 e suas sucessivas reedições. No geral, a MP refere-se aos critérios para aposentadoria e recebimento de benefícios por parte de diversas categorias de trabalhadores, de servidores públicos a trabalhadores rurais, modificando as leis nos 8.212 e 8.213, ambas de 24 de julho de 1991, que estabelecem a organização da Seguridade Social e os Planos de Benefícios da Previdência Social, respectivamente, integrando os planos de reestruturação do sistema previdenciário nacional. Uma se refere à aposentadoria dos juízes classistas do trabalho, a outra à readmissão de funcionário público já aposentado e as outras dez diretamente às regras do sistema previdenciário. Três delas se referiam aos critérios para aposentadoria do trabalhador rural, duas outras à vedação do recebimento de pensão 
por morte, duas outras aos critérios para aposentadorias especiais de trabalhadores com agentes nocivos e tóxicos, uma ao cálculo das contribuições, uma às contribuições das empresas e uma última à convalidação dos efeitos de edições anteriores da mesma MP. Entre os proponentes, o PT aparece sozinho em quatro Adins e juntamente com PDT e PC do B em outras quatro ações, das quais apenas uma foi julgada em desfavor do governo no que se refere aos critérios para aposentadoria dos trabalhadores rurais. As outras quatro ações foram apresentadas, respectivamente, pelo PPB (partido então integrante da base aliada), pela Confederação Nacional dos Trabalhadores na Indústria - CNTI, Associação Nacional dos Juízes Classistas da Justiça do Trabalho Anajucla e pela Confederação Nacional da Indústria - CNI, das quais apenas esta última teve seu pedido acolhido, referente à contribuição das empresas para o sistema previdenciário. Adins: 1.526, 1.533, 1.534, $1.580,1.636,1.637,1.641,1.659,1.664,1.665,1.686,1.699$. Resultado do julgamento: majoritariamente vitória do governo, que restou derrotado em apenas duas Adins (uma de PT/PDT/PC do B e outra da CNI).

Medida Provisória nº 1.415, de 29 de abril de 1996. Dispõe sobre os reajustes do salário mínimo (fixando-o em R $\$ 112,00$ ) e dos benefícios da Previdência Social (vinculados aos reajustes do mínimo), altera alíquotas de contribuição para a seguridade social e institui a contribuição previdenciária para os servidores inativos da União. As nove Adins se dirigem quase sempre contra a totalidade da MP ou contra partes extensas dela. O STF não interveio em nenhum dos casos, mas a contribuição dos inativos foi revista pelo próprio Executivo nas reedições seguintes da MP, provavelmente em razão das críticas provenientes do Congresso Nacional. Identificando os proponentes das diferentes Adins, observa-se que, nesse caso, há uma perfeita sintonia entre os partidos de esquerda e seus aliados tradicionais, sindicatos de trabalhadores e de servidores públicos. Entre os proponentes, encontram-se PT, PDT, PSB, PC do B, Central Única dos Trabalhadores - CUT, Confederação Nacional dos Trabalhadores na Agricultura - Contag, Confederação Nacional dos Trabalhadores na Indústria - CNTI, além de diversos sindicatos de servidores públicos, entre os quais inclusive alguns vinculados ao funcionalismo de órgãos previdenciários. Dado o teor da Adin e seus respectivos autores, parece o caso claro de uso político das Adins para, conjuntamente, declarar oposição a um salário dessa monta (que, em face do que exige a Constituição, é muito baixo) e igualmente desmerecer a medida do governo, visto que alegavam os requerentes, em síntese, que tal reajuste, por ser muito diminuto, não preservava o po- 
der aquisitivo do trabalhador. Adins: 1.439, 1.441, 1.442, 1.445, 1.447, $1.453,1.455,1.457,1.520$. Resultado do julgamento: noSTF, o governo restou vitorioso; no Congresso Nacional, houve algumas alterações do texto.

Lei n-9.504, de 30 de setembro de 1997. Regula a realização das eleições em todos os níveis (federal, estadual e municipal) no Brasil. Foi contestada em diferentes momentos, quase sempre por partidos pequenos. As sete Adins existentes foram propostas em 1998 (três delas) e em 2001, 2004, 2005 e 2007 as demais, uma em cada ano, respectivamente. Entre seus proponentes estão partidos como o Partido da Mobilização Nacional - PMN, PL (duas vezes), PPS, PSB, Partido Social Cristão PSC, além da Procuradoria-Geral da República - PGR. Quase todas buscam atacar regras eleitorais que, supostamente, dificultariam a sobrevivência política desses grupos (exceção feita à Adin proposta pela PGR, de no 2.530, que atendia à solicitação do TSE após requisição do senador Roberto Requião, do PMDB/PR, que buscava ampliar a liberdade de organização interna dos partidos políticos, evitando certas regras nesse sentido da referida lei). São regras que limitam o número de candidatos nas eleições proporcionais, que dispõem sobre a divisão do tempo de propaganda eleitoral na televisão, que instituem regras sobre a cassação de mandatos por abuso de poder econômico, que instituem prazos para a inscrição das candidaturas e procedimentos para a escolha dos candidatos, além da proibição de participação na inauguração de obras públicas de candidatos integrantes do Poder Executivo nos três meses que antecedem as eleições respectivas. $\mathrm{O}$ curioso a observar é que o STF não interveio em nenhum dos casos em que os proponentes foram partidos políticos (em cinco, as liminares ou o mérito foram negados e uma outra ainda está pendente), mas deferiu a liminar no caso da Adin proposta pela PGR, que questionava procedimentos para a escolha de candidatos em coligações entre partidos. Afirmava-se que essas regras feriam a liberdade de organização interna dos partidos políticos, argumento acolhido pelo STF. Adins: 1.813, 1.817, $1.822,2.530,3.305,3.592,3.986$. Resultado do julgamento: governo majoritariamente vitorioso (derrota apenas na Adin proposta pela PGR).

Lei no 9.601, de 21 de janeiro de 1998. Trata-se de lei que dispõe sobre o contrato de trabalho por prazo determinado e institui a liberdade de negociação das condições de trabalho (em empregos por prazo determinado) entre sindicatos e seus respectivos empregadores. Trata-se, como se vê, de lei que flexibiliza as relações entre capital e trabalho. A 
lei foi contestada em sete Adins nos dois meses seguintes, novamente seguindo o perfeito alinhamento entre partidos de esquerda e sindicatos, especialmente de trabalhadores na iniciativa privada. Entre os partidos proponentes, temos PT, PDT, PC do B e Partido Socialista dos Trabalhadores Unificado - PSTU. Quanto aos sindicatos, são muitos, mas fazem parte desse grupo CUT, Contag, CNTI, entre outros. O mais curioso é que, em que pese tenha sido acionado em 1998 e em todas as Adins houvesse pedido de liminar, seus respectivos julgamentos (de liminar) se encontram pendentes desde um pedido de vista do ministro Nelson Jobim em 1998. Curioso ainda é o fato de o ministro Jobim já ter deixado o tribunal e seu substituto também não ter encaminhado ainda o julgamento da questão. Adins: 1.764, 1.765, 1.766, 1.767, 1.768, 1.794, 1.816. Resultado do julgamento: a julgar pelo transcurso de tempo sem decisão de liminar pelo tribunal (dez anos), trata-se de vitória judicial do governo.

Emenda Constitucional n-20, de 15 de dezembro de 1998 (Reforma da Previdência). Trata-se de emenda à Constituição que modifica o sistema de previdência social, estabelece normas de transição e dá outras providências. Ao que parece, em que pese o número elevado de Adins, não houve uma litigiosidade muito elevada ao inteiro teor da reforma, provavelmente porque as negociações junto ao Congresso Nacional tenderam a tornar o projeto mais consensual e menos polêmico. O uso da via judicial atesta essa tendência. Prova disso é que o principal opositor ao governo Fernando Henrique, o PT, não apresentou nenhuma das ações propostas contra esse estatuto legal. E isso ocorreu apesar de o partido ter votado contra a reforma da previdência no Congresso Nacional e de esta ter atacado interesses diretos de segmentos historicamente alinhados ao partido, os trabalhadores na iniciativa privada. Entre os pontos mais destacados dessa reforma, podemos citar o fim da aposentadoria proporcional, a criação do chamado fator previdenciário e a substituição, na prática, da aposentadoria por tempo de serviço pela aposentadoria por tempo de contribuição. Apesar disso, nem o PT nem outros aliados históricos desse segmento (PDT e PC do B, por exemplo) apresentaram Adins contra essa emenda à Constituição. A única Adin apresentada no período imediato após a aprovação da emenda foi a de no 1.946, pelo PSB, que questionava apenas o limite de $\mathrm{R}$ \$1.200,00 como valor máximo para os benefícios da Previdência Social, especialmente no que se refere ao recebimento do auxílio-maternidade, pedido que foi atendido pelo STF no julgamento da liminar, sem redução de texto. As outras cinco ações propostas, todavia, foram 
apresentadas apenas seis meses depois da aprovação da emenda, sendo outras três entre 1999 e 2000 (por CNTI, governador do MS e mesa da Assembléia Legislativa do PR), e outras duas apenas em 2002 (por Partido Social Liberal - PSL e PV). As três primeiras questionavam, respectivamente, regras sobre o regime previdenciário dos servidores públicos, regras sobre contagem de tempo para aposentadoria e critérios para a aposentadoria de juízes. Por sua vez, as Adins propostas por PSL e PV questionavam a mesma regra, qual seja, a aposentadoria compulsória aos setenta anos de integrantes do STF, STJ, Tribunal de Contas da União - TCU, entre outros. Em todas essas cinco últimas ações, contudo, os proponentes não tiveram seus pedidos acolhidos pelo STF. Adins: 1.946, 2.024, 2.096, 2.242, 2.760, 2.883. Resultado do julgamento: vitória quase inteiramente do governo (houve uma única derrota na Adin proposta pelo PSB).

Lei Complementar n-101, de 4 de maio de 2000 (Lei de Responsabilidade Fiscal). Estabelece normas de finanças públicas voltadas para a responsabilidade na gestão fiscal e dá outras providências. Apenas uma das ações foi apresentada por partido político, a de no 2.365 , proposta pelo PC do $B$, contrária às regras de definição da repartição de recursos entre os Poderes Executivo e Legislativo no âmbito municipal, pedido que não foi acolhido pelo STF. As outras cinco ações foram apresentadas pelo governador de MG (contra os critérios para operações de crédito entre as entidades federativas), pela Associação dos Membros de Tribunais de Contas (em duas ações distintas, contra os limites de gasto dos três Poderes do Estado e a forma de prestação de contas dos mesmos, respectivamente), pela Associação Nacional dos Membros do Ministério Público (contra o limite de gastos da instituição no âmbito estadual) e pela Mesa Diretora da Assembléia Legislativa do DF (contra os limites de gasto dos diferentes órgãos do DF). Em nenhum dos casos, contudo, as ações foram acolhidas pelo STF, estando duas ainda pendentes quanto ao resultado. Adins: 2.250, 2.256, 2.261, 2.324, 2.365, 3.756. Resultado do julgamento: vitória do governo.

Lei n-9.096, de 20 de setembro de 1995. Lei que dispõe sobre partidos políticos, regulamentando os arts. 17 e 14, § 3ㅇ, inciso V da Constituição Federal. As duas primeiras dessas ações (n- 1.351 e 1.354) foram propostas conjuntamente por nada menos do que nove diferentes partidos políticos (oito na primeira: PT, PDT, PC do B, PSB, PL, PV, PPS, PSD; e um na segunda: PSC) contra o que poderíamos chamar de "cláusula de barreira", de que falam os arts. 13 e 41 da referida lei, que estipulavam 
que somente os partidos com no mínimo $5 \%$ dos votos apurados teriam direito a assento na Câmara dos Deputados e direito a receber verbas do fundo partidário. O tribunal acolheu o pedido e julgou diretamente o mérito da questão, declarando inconstitucionais tais dispositivos legais. Parece o caso novamente de "judicialização tradicional", na qual se buscava o aperfeiçoamento do sistema partidário e também assegurar a sobrevivência política de algumas dessas agremiações. Por sua vez, a Adin no 1.363 foi proposta pela mesa da Assembléia Legislativa da BA contra disposições sobre a dinâmica parlamentar dos partidos nos órgãos legislativos estaduais, mas não foi acolhida pelo tribunal. Há ainda uma ação (n-1.465) proposta pelo PFL contra os critérios para cancelamento de filiação partidária. O partido pretendia ter autonomia para estabelecer tais critérios, mas não foi acolhido pelo tribunal. Em 2002 (Adin n-2.677) ainda, o PTB propôs ação contra regras sobre a participação de outros candidatos em programas de outros partidos na televisão, mas sem sucesso. Por fim, em 2005, a Associação Brasileira de Eleitores propôs ação contra os quesitos para o registro de partidos políticos de caráter nacional, mas nem sequer teve sua ação julgada por se tratar de organização sem legitimidade ativa. Adins: 1.351, $1.354,1.363,1.465,2.677,3.606$. Resultado do julgamento: em parte, vitória do governo; em parte, dos proponentes (no que se refere à "cláusula de barreira").

Lei no 9.100, de 19 de setembro de 1995. Dispõe sobre a realização das eleições municipais de 3 de outubro de 1996. Novamente, parece ser o caso de "judicialização tradicional", buscando o aperfeiçoamento das regras eleitorais e, ao mesmo tempo, a melhoria das condições que propiciem a sobrevivência de alguns partidos. As seis ações foram propostas no período próximo ao da aprovação da lei, sendo cinco delas apresentadas por partidos políticos (duas vezes o PC do B; PDT, PL e PPB uma vez cada, respectivamente) e uma pela Associação Brasileira das Empresas de Rádio e Televisão, no caso, contra regra referente à cobertura do horário gratuito de rádio e televisão (indeferida). No caso das outras cinco Adins, elas questionavam regras referentes ao total de candidatos por coligação (deferida em parte), ao prazo para transferência de domicílio eleitoral (deferida), à simetria entre as coligações majoritárias e proporcionais (indeferida) e à distribuição do tempo de rádio e televisão para cada partido no interior da coligação (indeferida). Adins: 1.355, 1.382, 1.384, 1.407, 1.408, 1.490. Resultado do julgamento: na maior parte, o governo saiu vitorioso, mas os proponentes não foram 
mal-sucedidos (das seis ações, duas foram julgadas em favor de seus pedidos).

\section{GOVERNO LULA}

Resolução n² 21.702, de 2004, do Tribunal Superior Eleitoral. Regula o número de vereadores por município no Brasil, redistribuindo quantos devem existir em cada cidade em função da contagem da população. Ao adotar nova forma de realizar tal cálculo, na prática a resolução diminuiu o número total de vereadores existentes em cidades pequenas e o aumentou em cidades maiores. Em virtude da diminuição do número de cargos em municípios de pequeno porte, que provavelmente tornou mais difícil o acesso a esses postos, verificou-se uma espécie de avalanche de ações propostas especialmente por indivíduos contra a resolução do TSE: das 23 Adins apresentadas, dezenove foram propostas por vereadores, suplentes de vereadores, candidatos a vereador, coligações eleitorais locais, diretórios partidários municipais e integrantes de câmaras de vereadores de cidades de pelo menos nove Estados diferentes (GO, SP, PI, BA, PB, ES, PA, MS, PR), especialmente municípios de pequena população. Como parece claro, por não terem legitimidade ativa, suas ações nem sequer chegaram a ser efetivamente apreciadas pelo tribunal. Por sua vez, as quatro Adins restantes foram propostas por partidos políticos (PP, PDT e PL) e uma outra pela União de Vereadores do Brasil - UVB. Essas ações, entretanto, não foram acolhidas. Três tiveram seus pedidos negados, e uma está com o julgamento da liminar pendente. Adins: 3.214, 3.345, 3.348, 3.365, 3.372, 3.374, 3.375 , 3.382, 3.387, 3.393, 3.398, 3.400, 3.409, 3.411, 3.412, 3.414, 3.447, $3.448,3.455,3.492,3.611,3.693,3.822$. Resultado do julgamento: vitória do governo/TSE.

Emenda Constitucional no 41, de 19 de dezembro de 2003 (Reforma da Previdência). Modifica artigos da Constituição Federal, revoga parte de seu texto e ainda revoga a Emenda Constitucional nํ20, de 15 de dezembro de 1998, aprovada na gestão de Fernando Henrique. Em que pese a elevadíssima litigiosidade desse estatuto legal, apenas três Adins foram apresentadas por partidos políticos (PDT, Partido de Reedificação da Ordem Nacional - Prona e PTB, respectivamente). As doze outras ações que foram propostas resultaram da iniciativa de sindicatos e afins. Nesse particular, deve-se perceber a intensa participação de entidades ligadas a integrantes da burocracia judicial e jurídica, tais como a Associação dos Magistrados Brasileiros - AMB, Associação Nacional 
dos Magistrados da Justiça do Trabalho - Anamatra, Associação Nacional dos Membros do Ministério Público - Conamp, Associação Nacional dos Magistrados Estaduais - Anamages e Associação Nacional dos Procuradores Federais - Anpaf. As outras duas ações restantes foram propostas pela Associação dos Delegados de Polícia do Brasil Adepol e pela Confederação dos Servidores Públicos do Brasil - CSPB. A forte litigiosidade se explica também porque se dirigem contra diferentes momentos de implementação da emenda, voltando-se não apenas para seu texto, mas também contra resoluções que decorrem de sua aplicação a casos concretos, inclusive em decisões do Conselho Nacional de Justiça - CNJ e do Conselho Nacional do Ministério Público CNMP sobre os critérios para a aposentadoria de seus respectivos integrantes, por exemplo. Adins: 3.099, 3.104, 3.105, 3.128, 3.133, 3.138, $3.143,3.172,3.184,3.291,3.297,3.854,3.855,3.872$, 4.014. Resultado do julgamento: do que foi julgado até agora (nove Adins estão pendentes), em parte vitória do governo, em parte dos proponentes (das seis ações julgadas, uma foi integralmente deferida - referente ao subteto salarial das magistraturas estaduais - e outras duas foram parcialmente deferidas - sobre o percentual cabível à contribuição dos inativos, que ficou pendente, portanto, para futura regulamentação legislativa).

Emenda Constitucional n 45, de 8 de dezembro de 2004 (Reforma do Judiciário). Altera vários dispositivos da Constituição referentes à estrutura e às atribuições dos diferentes órgãos do Poder Judiciário e do Ministério Público, criand o o CNJ e o CNMP. Apesar da elevadíssima litigiosidade apresentada nesse tópico, é interessante notar que não há entre os proponentes nenhum partido político. Praticamente todas as Adins apresentadas foram ajuizadas por entidades de classe dos mais variados níveis: das quatorze ações apresentadas, treze foram ajuizadas por entidades de classe e apenas uma pela PGR. Há alguns pontos dessa emenda que levam às principais fontes de contestação judicial. Um deles é a criação dos órgãos superiores de administração da justiça e do Ministério Público e suas respectivas resoluções baixadas na seqüência da implementação das diretrizes desse estatuto legal. Pelo menos sete Adins foram propostas por diferentes entidades ligadas à magistratura (AMB, Anamatra, Anamages, entre outras), ao passo que duas foram propostas por órgãos vinculados ao Ministério Público, como o Conamp e a PGR. As outras ações foram propostas especialmente por entidades de trabalhadores que buscavam questionar reflexos trazidos pela emenda sobre a estrutura de apreciação do Poder Judiciário de determinadas questões, como o julgamento do direito de greve e a 
definição da natureza de algumas relações de trabalho, entre outros. Adins: 3.367, 3.392, 3.395, 3.423, 3.431, 3.432, 3.472, 3.486, 3.493, 3.520, $3.529,3.684,3.843,3.998$. Resultado do julgamento: do que foi julgado até agora (dez Adins estão pendentes), os proponentes resultaram majoritariamente vitoriosos (três das quatro ações julgadas deferiram os pedidos formulados), especialmente no que se refere à competência para o julgamento dos conflitos provenientes das relações de trabalho de servidores públicos.

Lei n-10.826, de 22 de dezembro de 2003 (Estatuto do Desarmamento). Trata-se de lei que dispõe sobre registro, posse e comercialização de armas de fogo e munição, instituindo o chamado Sistema Nacional de Registro de Armas - Sinarm, definindo inclusive crimes referentes a algumas práticas ligadas a essas atividades. Ao todo, quatro ações foram propostas pela Adepol, uma pela Confederação Nacional dos Vigilantes, Empregados em Empresas de Segurança, Vigilância e Transportes de Valores e dos Cursos de Formação e Especialização de Vigilantes, Prestação de Serviços Similares e seus anexos e afins (CNTV), uma pela Confederação Nacional do Comércio - CNC e uma pelo diretório municipal do PSDB de Itu/SP. Elas questionavam diferentes partes da lei, mas sobretudo as novas regras para aquisição de armamento, os agentes habilitados para tanto, a criminalização da posse de armas de fogo sem licença, entre outros. Como parece, trata-se de uma judicialização especialmente provocada pelos agentes diretamente interessados na questão, como policiais e vigilantes, mas não há nenhum posicionamento firmado pela corte em nenhuma dessas ações até o presente momento. Adins: 3.102, 3.263, 3.518, 3.586, 3.600, 3.788, 3.814. Resultado do julgamento: todas as Adins estão pendentes.

Lei n⿳ำ 11.300, de 10 de maio de 2006. Dispõe sobre propaganda, financiamento e prestação de contas referentes a campanhas eleitorais, alterando a Lei no 9.504, de 30 de setembro de 1997. Instituiu mais rigor na prestação de contas de campanhas eleitorais e conferiu mais responsabilidade aos candidatos nesse processo, tornando mais rígidas outras regras atinentes ao pleito. Em virtude disso, foram propostas quatro Adins por partidos políticos (PSC, PDT, Partido Trabalhista Cristão PTC e PL), às quais se somou uma outra proposta pela Ordem dos Músicos do Brasil - OMB. Enquanto as ações dos partidos buscavam atacar praticamente na íntegra o texto da lei, a OMB buscava ver revogada a proibição de showmícios em campanhas eleitorais. Por fim, duas ações foram julgadas parcialmente procedentes na parte referente ao prazo 
final para publicação de pesquisas eleitorais de opinião. Adins: 3.741, $3.742,3.743,3.758,3.759$. Resultado do julgamento: vitória majoritariamente do governo (mas houve duas derrotas).

Lei Complementar n-123, de 14 de dezembro de 2006. Instituiu o Estatuto Nacional da Microempresa e da Empresa de Pequeno Porte (Simples Nacional) e colocou sob a alçada de órgãos da União a gestão, a aplicação de normas e a solução de controvérsias decorrentes da implementação desse novo regime tributário para as empresas de pequeno porte. Em função disso, gerou demandas de representantes de funcionários de órgãos estaduais que buscavam ver sob sua jurisdição tais funções. É o caso das Adins ajuizadas por entidades como a Associação Nacional dos Procuradores de Estado - Anape, a Confederação dos Servidores Públicos do Brasil - CSPB e a Federação Brasileira de Associação de Fiscais de Tributos Estaduais (FebraFite). Igualmente, os critérios de aplicação do Simples Nacional excluíram algumas categorias de empresas, gerando contestação da Confederação Nacional dos Trabalhadores nas Empresas de Crédito - Contec e da Confederação Nacional do Comércio - CNC. Por fim, das cinco ações propostas, duas foram declaradas prejudicadas, uma teve o pedido de liminar indeferido e duas aguardam julgamento. Adins: 3.903, 3.906, 3.910, 3.933, 4.033. Resultado do julgamento: até agora, vitória do governo (duas estão pendentes).

Medida Provisória n-131, de 25 de setembro de 2003. A MP estabelece normas relativas ao plantio e à comercialização da produção de soja da safra de 2004, especialmente no que se refere àquela geneticamente modificada. De fundamental, percebe-se que a MP liberava o plantio e a comercialização desse tipo de grãos em contrariedade ao esperado. Trata-se de um conjunto de ações promovidas por amplo leque de forças políticas, entre as quais tradicionais aliados petistas (Contag e PV, respectivamente, sendo este último integrante da coalizão governista na época), a Procuradoria Geral da República e o PFL/DEM. Todas as ações foram propostas no período imediatamente posterior à edição da MP e acabaram declaradas prejudicadas pela falta de aditamento ao pedido inicial da lei que resultou da conversão da MP. Parece ser o caso de oposição a essa política do governo, mesmo que um dos proponentes fosse integrante da própria coalizão governista. Adins: 3.011, 3.014, 3.017, 3.036. Resultado do julgamento: vitória do governo. 
Medida Provisória n-135, de 30 de outubro de 2003. Altera a Legislação Tributária Federal, reformulando amplamente as regras que regem a Contribuição para o Financiamento da Seguridade Social - Cofins. Ela foi atacada quase imediatamente no mês imediatamente posterior à sua edição por quatro ações, três propostas respectivamente por PFL/DEM, PSDB, Prona e uma outra de autoria da Confederação Nacional dos Transportes - CNT. Todas as ações questionavam de forma praticamente integral a MP. Pode-se observar com clareza que o objetivo dessas ações era fundamentalmente declarar oposição às medidas adotadas pelo governo. Das quatro ações, três foram declaradas prejudicadas pela não-adição ao pedido inicial em vista da posterior conversão em lei da MP atacada. A outra ação ainda aguarda julgamento. Adins: 3.044, 3.047, 3.048, 3.067. Resultado do julgamento: até agora, vitória do governo (uma Adin está pendente).

Medida Provisória nº 349, de 22 de janeiro de 2007. Instituiu o Fundo de Investimentos do FGTS, sendo contestada integralmente por quatro Adins propostas no período imediatamente posterior ao de sua edição. Entre seus proponentes estão PFL/DEM e confederações sindicais de trabalhadores de diversas categorias (metalúrgicos, trabalhadores em empresas de crédito, no turismo, entre outras). Parece claro o objetivo oposicionista do PFL/DEM ao propor essa Adin, mas no mínimo é curioso observar que o partido se colocou ao lado de aliados históricos do PT, como os metalúrgicos. Finalmente, foram todas as ações julgadas prejudicadas pela falta de aditamento ao pedido inicial pela posterior conversão em lei da medida provisória atacada. Adins: 3.849, 3.851, $3.864,3.881$. Resultado do julgamento: vitória do governo. 


\section{ABSTRACT \\ Political Parties In and Out of Power in Brazil: Judicialization as a Contingent Result of Political Strategy}

The article analyzes the judicialization patterns in politics during the two terms of President Fernando Henrique Cardoso (1995-2002) and compare them to the subsequent period of slightly less than a term and a half under President Luiz Inácio Lula da Silva (2003-2008). The purpose of the comparison was to observe whether appeals were issued to the Supreme Court challenging Federal acts on grounds of unconstitutionality. Both differences were observed and some common uses of judicialization when comparing the two Presidential Administrations.

Key words: political parties; judicialization of politics; Supreme Court; Fernando Henrique administration; Lula administration

\section{RÉSUMÉ}

Les Partis dans et Hors le Pouvoir: La Judicialisation comme Résultat Éventuel des Stratégies Politiques

Dans cet article, on examine les modèles de recours en appel à la Cour Suprême de Justice employés par les hommes politiques pendant les deux mandats du président Fernando Henrique Cardoso (1995-2002) et on les compare à la période suivante concernant le mandat et demi du président Luiz Inácio Lula da Silva (2003-2008). On cherche à savoir si l'on trouve des différences dans la façon de faire appel à la Cour Suprême de Justice pour la contestation d'actes du pouvoir fédéral par le moyen de l'Action Directe d'Inconstitutionnalité. On a trouvé, à ce sujet, entre les deux gouvernements, des disparités mais aussi certains usages communs.

Mots-clé: partis politiques; judicialisation; Cour Suprême de Justice; gouvernement Fernando Henrique; gouvernement Lula 